\title{
POLA PEMBINAAN BERDASARKAN EFESUS 5 : 22- 33 BAGI PERNIKAHAN DINI WARGA JEMAAT MASA KINI
}

\author{
Rafles Rudi Laua
}

\section{PENDAHULUAN}

Pernikahan merupakan salah satu pokok penting dalam pelayanan gereja, karena selalu berhubungan dengan jemaat dimana kita melayani. Persoalan-persoalan yang sering dihadapi oleh pemimpin gereja adalah soal usia pernikahan, dan pada umumnya pelayanan di desa selalu hal inilah yang menjadi permasalahan.Di dalam Undang-undang Perkawinan Nomor I tahun 1974 Bab II pasal 6 ayat 22) Untuk melangsungkan perkawinan seorang yang belum mencapai umur 21 (dua puluh satu) tahun harus mendapat izin kedua orang tua. ${ }^{1}$ Penjelasan pasal 6 ini mengisyaratkan bahwa batas usia yang ideal dalam perkawinan adalah usia 21 tahun, banyak hal yang harus dipertimbangkan mengapa usia perkawinan perlu dipertimbangkan. Sesungguhnya sejak Allah menciptakan manusia, Allah sudah merancangkan sebuah pernikahan itu. .

Di dalam Kejadian 26 :27 - 28 “ Maka Allah menciptakan manusia itu menurut gambar-Nya menurut gambar Allah diciptakan-Nya dia; laki-laki dan perempuan diciptakan-Nya mereka. Allah memberkati mereka lalu Allah berfirman kepada mereka "beranak cuculah dan bertambah banyak; penuhilah bumi dan taklukkanlah itu, berkuasalah atas ikan-ikan di laut dan burung-burung di udara dan atas segala binatang yang merayap di bumi.

Allah sendiri menginisiatif bahwa manusia adam tidaklah sendiri berada di taman itu, sebab ciptaaan Allah tidak ada yang sepadan dengan Adam, maka Allah akhirnya menciptakan Hawa sebagai pendamping untuk menjalin hubungan dan memberikan keturunan untuk berkembang.

Pernikahan sesuatu yang Allah sendiri rancang, dan manusia melaksanakannnya, hidup pernikahan dan menjalin keluarga sangatlah sebuah tugas mulia manusia, yang menjadi pertanyaan adalah sejauhmana manusia melaksanakan tugas itu sendiri. Hidup pernikahan dan keluarga Kristen di akhir zaman ini sungguh menghadapi suatu tantangan yang sangat berat ,mengapa demikian? Jawabannya adalah karena hidup pernikahan dan keluarga bukanlah sesuatu statis, kaku dan mati , melainkan suatu kehidupan yang dinamis. Di dalam Undang-undang Perkawinan Nomor 1 tahun 1974, pasal 6 ayat 2, Untuk melangsungkan perkawinan seorang yang belum mencapai umur 21 (dua puluh satu ) harus mendapat izin kedua orang tua. $^{2}$ Penjelesan pasal 6 ini menginsyaratkan bahwa batas usia yang ideal dalam perkawinan adalah 21 tahun, banyak hal yang dipertimbangkan baik usia perkawinan memang perlu menjadi batasan-batasan kematangan seseorang. Sejak Allah menciptakan manusia. Allah merancangkan sebuah pernikahan itu.

Dalam kejadian 26 : 27 -28 "Maka Allah menciptakan manusia itu menurut gambar-Nya menurut gambar Allah dicitakannya dia; laki-laki dan perempuan

\footnotetext{
${ }^{1}$ UU Pernikahan

${ }^{2}$ UU Perkawinan No. 1 Th. 1974
} 
diciptakanNya mereka . Allah memberkati mereka lalu Allah berfirman kepada mereka "Beranak cuculah dan bertambah banyak; penuhilah bumi dan taklukkanlah itu. Berkuasalah atas ikan-ikan di laut dan burung-burung di udara dan atas segala binatang yang merayap di bumi.

Allah sendiri berinisiatif bahwa manusia Adam tidaklah sendiri berada di taman itu, sebab ciptaan Allah tidak ada yang sepadan dengan Adam, maka Allah akhirnya menciptakan Hawa sebagai pendamping untuk menjalin hubungan dan memberikan keturunan yang berkembang

Merupakan amanat Allah kepada manusia untuk berkembang melalui hubungan Di era modern ini, tugas gereja mencakup berbagai masalah-masalah yang dihadapi dalam berjemaat dan salah satunya adalah masalah pernikahan. Tantangan ini cukuplah besar. Dimulai masalah-masalah dalam rumah tangga Kristen, yang terus menerus menjadi problema dalam hidup dan menjadi problema dalam hidup berjemaat, secara keseluruhan, dan gangguan-gangguan it uterus menerus terjadi. Pertanyaan mengapa hal itu terus dialami jemaat?.

Keberadaan dialami pada keluarga Kristen masa kini, semakin banyak tantangan dalam pelayanan, bahkan dapat dikatakan sasaran yang paling banyak justru orang-orang Kristen. Melihat gambaran kehidupan masa kini perlu kita kembali kepada ajaran-ajaran kekristenan bagaimana kehidupan rumah tangga itu. Sasaran iblis sangatlah kuat mempengaruhi keberadaan hidup rumah tangga Kristen masa kini, yang juga mempengaruhi kehidupan orang-orang Kristen. Maka kita perlu kembali bertanya apakah pernikahan itu ? Mengapa manusia ingin menikah ? Dan mengapa kita menikah ? apa tujuan kita menikah dan berkeluarga ? Unsur mendasar yang perlu dipahami bagi mereka yang akan dan sudah menikah adalah bahwa pernikahan adalah suatu tahap dari sekian banyak tahap kehidupan seseorang. ${ }^{3}$

Pernikahan adalah amanat Allah kepada manusia untuk berkembang melalui hubungan perkawinan, maka setiap individu ketika usia sudah mencapai kematangan, manusia harus menjalin hubungan dengan lawan jenis. Masalah-masalah yang dihadapi oleh gereja masa kini adalah banyaknya jemaat yang juga masih di bawah usia dalam ketentuan umum, baik secara pemerintahan maupun secara bergereja. Sehingga kematangan dalam berumah tangga selalu terjadi konflik-konflik yang sulit dipecahkan. Kematangan mental berumah tangga sangat mempengaruhi hubungan baik antara suami-istri.

Allah menjadi pernikahan tidak dapat dipisahkan dari diri-Nya , Tuhan melindungi dalam setiap bahaya yang mengancam suatu rumah tangga. Allah sendiri menjamin pernikahan tersebut, tergantung kendali kita apakah kita mampu mempertahankan ataukah kita memang sudah tidak mampu lagi mengatasinya?

\section{PERNIKAHAN KRISTEN}

Pernikahan merupakan masalah yang sangat serius pada masa kini dan penuh dengan persoalan-persoalan yang kompleks, hal itu sesungguhnya sudah ada sejak zaman dahulu, dan semenjak manusia berbuat dosa, maka kemuliaan Tuhan juga undur daripada manusia. Pernikahan merupakan amanat Allah kepada manusia untuk berkembang melalui hubungan perkawinan, maka setiap individu ketika

\footnotetext{
${ }^{3}$ Marulak Pasaribu, Pernikahan Dan Keluarga Kristen..., 5
} 
usianya sudah mencapai kematangan, manusia itu nharus menjalin hubungan dengan lawan jenisnya, Pernikahan merupakan anugerah yang Allah berikan kepada manusia dan sejak awal penciptaan manusia Adam, maka Allah memberikan pendamping seorang yang sepadan.

Allah menciptakan laki- laki dan perempuan menurut gambar dan rupa Allah (Kejadian 1 : 26) Untuk membangun rumah, kita membutuhkan desain dan cetak biru seorang arsitek. Kita menginginkan desain rumah tersebut indah dan nyaman, seperti yang kita idamkan. Kita pun membutuhkan rancangan dari perancang bijaksana untuk membangun rumah tangga yang bahagia. ${ }^{4}$

\section{Pernikahan Adalah Suatu Perjanjian (Covenant )}

Perkawinan merupakan suatu perjanjian yang dibuat oleh dua insan yang ingin bersatu dengan ikatan yang didasari oleh hukum yang akan mengikat mereka baik itu hukum gereja maupun hukum oleh pemerintah. Secara simbolis, orang yang menikah mengucapkan janji nikahnya di gereja. Secara sederhana, perjanjian adalah suatu persetujuan antara dua individu/kelompok atau lebih. Perjanjian pernikahan adalah mengasihi ("to love") dan dikasihi ("to be loved"). Menurut Balswick, ada tiga hal yang dapat kita pelajari dari perjanjian yang Allah tetapkan. Pertama, perjanjian itu sepenuhnya merupakan tindakan Allah, bukan sesuatu yang bersifat kontrak. Komitmen Allah ini tetap berlangsung, tidak bergantung pada manusia. Kedua, Allah menghendaki respons dari manusia. Namun, ini bukan berarti perjanjian tersebut bersifat kondisional. Perjanjian itu tetap menjadi satu perjanjian yang kekal, terlepas dari apakah umat Tuhan melakukannya atau tidak. Ketiga, Allah menyediakan berkat-berkat dan keuntungan bagi mereka yang menuruti perjanjian tersebut. Manusia diberi kebebasan untuk memilih, untuk hidup dalam perjanjian itu atau menolaknya. ${ }^{5}$

Tujuan Pernikahan merupakan jalinan kasih yang yang disepakati dalam suatu ikatan janji yang diwujudkan dalam kehidupan bersama. Kebahagiaan merupakan wujud dan angan-angan setiap pasangan. Benarkah demikian, Kebahagiaan itu justru ditemukan di tengah-tengah perjalanan (proses) pernikahan yang dilandasi cinta kasih Kristus. Kalau tujuan kita menikah adalah bahagia, maka pasangan kita akan kita peralat demi mencapai kebahagiaan itu. ${ }^{6}$ Itu sebabnya, orang yang menikah dengan tujuan bahagia justru menjadi yang paling tidak bahagia dalam pernikahannya. Bahkan, tujuan ini banyak mengakibatkan perceraian, dengan alasan ia tidak merasa bahagia dengan pasangannya.

Heuken ${ }^{7}$ menyebutkan beberapa tujuan lain yang tidak kuat sebagai landasan untuk menikah. Pertama, demi keperluan psikologis, yakni supaya merasa tidak sendirian atau kesepian. Kedua, demi kebutuhan biologis, yakni agar dapat memuaskan nafsu seks secara wajar. Ketiga, demi rasa aman, yakni supaya memunyai status sosial dan dihargai masyarakat. Keempat, agar memunyai anak. Ini semua bukan merupakan alasan atau tujuan yang kuat mengapa seseorang menikah.

\footnotetext{
${ }^{4}$ James \& Martha Reapsome, Rancangan Allah Bagi Pernikahan, (Jakarta: Literatur Perkantas, $2006), 10$

${ }^{5}$ Balswick \& Balswick “ The Family : A Christian Perpectiveon the Contemporary Home, (Grand Rapids,Minchigan Baker Book House , 1991) 23

${ }^{6}$ Heuken " Persiapan Perkawinan ,“( Yogyakata: Kanisius ) 18-19

${ }^{7}$ Ibid., 18-19
} 


\section{Pernikahan Adalah Suatu Perjanjian Abadi}

Dimaksudkan denga pengertian ini adalah bahwa pernikahan bukanlah janji sesaat melainkan janji sehidup-semati artinya hanya kematianlah yang memisahkan dua insan yang menyatakan janji itu. Itu sebabnya dalam janji pernikahan para hamba Tuhan selalu meminta mengulangi janji itu,dalam keadaan sehat maupun sakit, dalam keadaan ataupun dalam keadaan kaya maupun miskin.

Dalam berumah tangga, kita akan mengalami begitu banyak keadaan dan situasi yang tidak diharapkan. Misalnya, pasangan Anda gagal dalam pekerjaan. Pasangan Anda menyeleweng. Pasangan Anda sakit atau cacat. Kondisi itu pasti tidak menyenangkan. Tetapi kalau Tuhan mengizinkan hal-hal tersebut terjadi, kita perlu belajar dari hal-hal tersebut. Lewat situasi dan keadaan itulah cinta kita diuji, apakah kita tetap berpegang teguh pada janji pernikahan kita dan setia kepada pasangan kita sampai kematian memisahkan. Untuk itu, mari kita pahami tujuan pernikahan Kristen yang akan menguatkan tiang pernikahan kita.

Perjanjian abadi sesuatu yang diwujudkan dalam mempertahankan rumah tangga yang dijalani, inilah yang dipastikan diinginkan setiap pasangan.

\section{Pernikahan Adalah Menciptakan Komunitas Baru}

Kalau kita mengkaji lebih jauh bahwa pernikahan juga akan menciptakan komunitas baru yang dimaksudkan adalah pernikahan akan menghasilkan suatu identitas baru yang disebut keluarga yang terdiri dari : suami, istri dan anak .

John Stott mengatakan bahwa pernikahan dibentuk Allah dengan tujuan untuk menciptakan satu masyarakat baru milik Allah ("God's new society"), satu masyarakat tebusan yang dapat menjadi berkat dan membawa kesejahteraan bagi sesamanya. ${ }^{8}$

Wadah yang Allah pilih sebagai sarana menyejahterakan manusia tebusan-Nya di dunia ini adalah keluarga. Rencana ini telah Allah tetapkan jauh sebelum manusia jatuh ke dalam dosa. Untuk itu, Allah pertama-tama memilih keluarga Abraham, Ishak, Yakub, dan seterusnya sampai akhirnya dalam keluarga Yusuf dan Maria yang melahirkan Yesus. Demikianlah sampai hari ini, rencana Tuhan bagi setiap pasangan Kristen adalah agar pasangan itu menghasilkan anak-anak perjanjian (anak-anak Tuhan) yang memunyai tanggung jawab untuk merawat dan mengurus bumi ciptaanNya ini. ${ }^{9}$ (Kejadian 1:26, 28)

Di samping itu, melalui setiap keluarga, Allah menghendaki agar setiap suami istri melahirkan keturunan ilahi (anak-anak tebusan Kristus. Baca Maleakhi 2:14-15). Karena itu, berdasarkan prinsip di atas, saya berkeyakinan bahwa setiap anak dalam pernikahan kami adalah anak-anak (karunia/titipan) Tuhan. Mereka bukan baru menjadi anak-anak Tuhan saat mereka dibaptis atau sesudah besar, tetapi sejak dalam kandungan mereka adalah benih ilahi yang Allah percayakan kepada keluarga kami.

Keyakinan ini sangat memengaruhi sikap kita dalam menghargai dan mendidik anak-anak. Juga akan membuat kita memprioritaskan keluarga dengan benar. Tujuan kita adalah mendidik mereka agar menjadi anak-anak Tuhan yang tidak hanya menaati bapak dan ibu mereka secara daging, tetapi juga taat kepada Bapa di surga. Kita juga sungguh-sungguh berusaha membangun kehidupan anak-anak kita, baik

\footnotetext{
${ }^{8}$ Jhon Stott .:Isu-isu global : menentang Kepemipinan Kristiani “ (Surabaya: Komunitas Bina Kasih/OMF, 1984), 24

${ }^{9}$ Yakub Susabda. Pastoral Konseling Jiliid 2 ( Malang : Gandum Mas ), 56
} 
secara fisik, mental, maupun spiritual. Tetapi jika Tuhan mengizinkan keluarga kita tanpa seorang anak, rencana Tuhan pun tetap sama indahnya. Dia mempunyai rencana tersendiri bagi keluarga yang tidak dikaruniai anak. Keluarga yang demikian perlu bergumul, mencari tahu apa yang dapat diperbuat untuk menyenangkan hati Tuhan, meski belum ada buah hati. Jika ingin mengadopsi anak, sebaiknya berkonsultasi terlebih dulu dengan konselor..

Anak merupakan upah atau berkat Tuhan bagi keluarga yang dikenan-Nya untuk menerima berkat itu. Tidak memiliki anak bukan berarti dikutuk atau tidak mendapat berkat Allah. Suami istri yang tidak memiliki anak pun, tetap merupakan keluarga yang di dalamnya Allah memiliki rencana tersendiri.

Pengertian Pernikahan itu sendiri tidakah terlepas dari rencana Allah bagi manusia dimana salah satunya adalah meneruskan keturunan yang akan menjadi perkembangan manusia di dalam dunia ini.

\section{PENGERTIAN HAKEKAT PERNIKAHAN MENURUT ALKITAB}

Hakikat pernikahan sesungguhnya komitmen total dua orang di hadapan Tuhan, dan pernikahan yang baik adalah didasari atas kesadaran bahwa pernikahan itu adalah kemitraan yang dijalin oleh dua insan yang saling mencintai satu sama lain, sebab pernikahan itu adalah sebuah rencana ilahi yang istimewa. Maka wajiblah kita harus menjaga dengan sebaik - baiknya.

Kajian Penulis menilai berdasarkan alkitab ,khususnya kajian didasari oleh kitab Efesus $5: 22-33$ berikut kajian :

\section{Pengertian sikap suami istri}

Menurut WJS Poerwadarminta mengatakan Sikap (Pasangan) adalah persiapan untuk bertindak, bertingkah laku, perbuatan. Jadi sikap suami istri ialah tindakan atau perbuatan suami istri dalam menjalani kehidupan berkeluarga yang menuju keluarga yang bahagia

\section{Hakekat Suami Isteri}

Allah berfirman dalam Kejadian 2: 18 "tidak baik, kalau manusia itu seorang diri saja. Aku akan menjadikan penolong baginya yang sepadan dengan dia." Hal inilah membuat manusia di tempatkan Tuhan berpasang-pasangan. Setiap orang memiliki pemahaman yang berbeda tentang perkawinan. Hal itu tergantung kepada apa alasan dan tujuan mereka untuk menikah. Di bawah ini penulis akan menguraikan dari beberapa tokoh mengenai pengertian perkawinan yakni: di dalam Kamus Besar Bahasa Indonesia, Perkawinan berasal dari kata "kawin" yang artinya: "membentuk keluarga dengan lawan jenis" ${ }^{10}$ dan menurut Undang-undang No 1 Tahun 1974, pasal 1 bahwa: "Perkawinan adalah ikatan lahir dan batin antara seorang pria dan wanita sebagai suami Isteri melaksanakan Dharma agar memperoleh kebahagiaan dalam kehidupan sekarang ini ataupun kehidupan yang akan datang.

Kehidupan sekarang ini ataupun kehidupan yang akan datang. Dasar perkawinan ini tidak bisa lain darn cinta. Berdasarkan hubungan jasa-jasa yang

${ }^{10}$ Wanda Hmble, Persiapan Pernikahan Keluarga Menuju Rumah Tangga Yg Bahagia, (Yogyakarta : STII, 1997), 2 
lampau atau sekarang seorang pria dan wanita sebagai suami Isteri dengan tujuan membentuk keluarga (rumah tangga) yang bahagia dan kekal berdasarkan Ketuhanan Yang Maha Esa.

Ikatan lahir batin antara suami Isteri ini juga harus dilandasi dengan rasa saling kasih mengasihi, bantu membantu serta membagi suka dan duka antar satu dengan yang lain, demikian juga dengan harta benda bukan lagi disebut milikku atau milikmu tetapi menjadi milik kita. Selanjutnya juga dikatakan bahwa; "bila wanita dan pria keduanya mengharapkan berjodoh satu sama lain dalam kehidupan sekarang ini dan dalam kehidupan yang akan datang mereka harus memiliki kepercayaan yang sebanding, budi pekerti yang sebanding, kemurahan hati yang sebanding dan bijaksana yang dilakukan.

Landasan Hostoris tentang pernikahan, merupakan dasar mengetahui apa sesungguhnya pernikahan itu didasari oleh Historis sejak Perjanjian lama sampai masa kini. Apa yang alkitab katakan tentang pernikahan. Alkitab memandang bahwa pernikahan merupakan suatu ikatan dua insan yang berbeda jenis, dan dipersatukan dalam ikatan pernikahan.

Memahami pengertian tentang perkawinan dan hakikat perkawinan layak dan perlu dimiliki oleh setiap orang yang telah mengambil keputusan untuk menikah. Jangan sampai sepasang calon mempelai menghadapi kehidupan perkawinan dengan pikiran dan hati yang kosong.

Berikut ini akan dijelaskan tentang definisi, pengertian dan hakikat perkawinan Kristen. Selayaknyalah setiap orang yang mengambil keputusan untuk menikah memahaminya.

\section{Definisi Perkawinan Kristen}

Sebelum menetapkan rumusan, batasan atau definisi tentang perkawinan Kristen, terlebih dahulu kita simak apa kata Undang-Undang Perkawinan yang telah ditetapkan oleh Pemerintah pada tahun 1974. Undang-Undang Perkawinan tahun 1974 merumuskan bahwa "Perkawinan ialah ikatan lahir batin antara seorang pria dengan seorang wanita sebagai suami isteri dengan tujuan membentuk keluarga (rumah tangga-) yang bahagia dan kekal berdasarkan Ketuhanan Yang Maha Esa."

Catatan yang dapat kita berikan atas rumusan ini ialah: Perkawinan itu bersifat utuh atau bulat, yang meliputi keadaan lahir maupun batin. Perkawinan itu bersifat hiteroseksual - monogami, yaitu terdiri dari seorang pria dan seorang wanita. Tujuan dari lembaga perkawinan adalah membentuk keluarga yang bahagia, bahkan tidak hanya bahagia, tetapi juga kekal. Bahwasanya perkawinan itu berdasarkan Ketuhanan Yang Maha Esa. Bukan berdasarkan tradisi maupun dorongan biologis semata-mata. Lebih dari itu Perkawinan Kristen memiliki karakteristik yang berbeda.

Perkawinan Kristen bukan hanya berdasarkan Ketuhanan, melainkan direncanakan, ditetapkan dan diatur oleh TUHAN. Perkawinan Kristen dirumuskan sebagai suatu persekutuan hidup total dalam pertalian kasih antara seorang laki-laki dan seorang perempuan yang berlangsung seumur hidup yang dimeteraikan dengan berkat nikah kudus. Berdasarkan definisi di atas, berikut ini dijelaskan 5 (lima) kebenaran yang terkandung di dalamnya. 


\section{Perkawinan Kristen Adalah Persekutuan Hidup Total}

Perkawinan Kristen disebut persekutuan hidup karena persekutuan itu diakui eksistensinya seumur hidup, dan atau jika kedua-duanya masih hidup. Jika salah satunya telah meninggal dunia, maka persekutuan hidup itu selesai. Hukum yang mengikatnya sudah berakhir dan dimungkinkan pihak yang masih hidup akan menikah lagi untuk membentuk persekutuan hidup yang baru (Roma 7:2). Perkawinan Kristen disebut persekutuan hidup total karena persekutuan hidup itu meliputi seluruh aspek hidup, aspek kehidupan dan aspek penghidupan.

a. Aspek hidup

Aspek hidup meliputi unsur roh, jiwa dan tubuh. Persekutuan roh berbicara tentang perkawinan seiman. Persekutuan jiwa berbicara tentang kesatuan hati, kesatuan pikiran, kesatuan perasaan dan kesatuan kehendak. Dan persekutuan tubuh berbicara tentang relasi seksual.

b. Aspek kehidupan

Aspek kehidupan meliputi unsur keluarga dan kaum keluarga, dan unsur-unsur kepribadian yang menyangkut perbedaan individu. Masing-masing pribadi mengakui bahwa keluarga pasangannya telah menjadi keluarganya sendiri. Kepribadian pasangannya telah menyatu dengan pribadinya sendiri tanpa kehilangan identitasnya masing-masing. Dan perbedaan individu menjadi kekayaan untuk membangun keluarga yang bahagia.

c. Aspek penghidupan

Aspek penghidupan meliputi unsur ekonomi, kekayaan dan penggunaanya dalam kehidupan. Undang-undang perkawinan membedakan kekayaan bawaan dan kekayaan bersama. Kekayaan bawaan ialah kekayaan yang telah dimiliki oleh masing-masing pihak sebelum mereka menikah, sedangkan kekayaan bersama ialah kekayaan yang diperoleh secara bersama-sama selama mereka menikah. Pengaturan demikian berkait dengan penggunaan hak atas kekayaan masing-masing dan untuk menghadapi kemungkinan perceraian. Jika suatu perkawinan mengalami perceraian, maka kekayaan bawaan kembali kepada masing-masing pihak. Di dalam perkawinan Kristen tidaklah berlaku seketat itu, sebab dalam perkawinan Kristen tidak dipola untuk bercerai atau hidup secara terkotak-kotak. Segala kekayaan yang ada adalah kekayaan bersama yang dianugerahkan TUHAN kepada mereka. Ekonomi dan kekayaan bukan menjadi faktor pembeda dan pengotakan, melainkan menjadi berkat yang mempersatukan. Hukum ekonomi yang berlaku bukan lagi hukum ekonomi pribadi, melainkan hukum ekonomi keluarga yang berada di bawah otoritas TUHAN sendiri.

\section{Perkawinan Kristen Terjadi Karena Pertalian Kasih}

Perkawinan kristen terjadi bukan semata-mata untuk menyalurkan libido, bukan karena paksaan atau karena tradisi, melainkan karena kasih. Kasih yang mengalir dari Allah. Mula-mula kasih eros dan kemudian di dalamnya bermuatan kasih agape. Kasih eros saja tidak cukup untuk membangun keluarga Allah. Oleh karena itu Allah menganugerahkan kasih agape. Kasih agape adalah kasih yang hanya untuk mengasihi, tidak menuntut persyaratan tertentu, kasih yang hanya untuk berkorban bagi pihak yang dikasihi. Hal demikian telah dicontohkan sendiri oleh 
Allah, Dia menyerahkan dan mengorbankan Anak-Nya yang tunggal supaya dunia yang berdosa diselamatkan oleh-Nya (Yoh 3:16).

\section{Perkawinan Kristen Itu Hiteroseksual}

Pernyataan ini menunjuk pada pola perkawinan Kristen sejati. Bahwasanya perkawinan itu bersifat hiteroseksual-monogami, bukan biseksual atau homoseksual yang poligami atau poliandri. Allah akan memberi hukuman bagi mereka yang melanggar ketentuan-Nya ini. Perhatikan firman-Nya ini: "Bila seorang laki-laki tidur dengan laki-laki secara orang bersetubuh dengan perempuan, jadi keduanya melakukan suatu kekejian, pastilah mereka dihukum mati dan darah mereka tertimpa kepada mereka sendiri." (Im 20:13 band Roma 1:25,26).

\section{Perkawinan Kristen Itu Abadi}

Perkawinan itu berlangsung seumur hidup, hal itu berarti bahwa di dalam perkawinan Kristen tidak ada pembatalan atau perceraian. Perkawinan Kristen hanya mengenal cerai mati, bukan cerai hidup. Selama kedua-duanya masih hidup tidak ada pembatalan atau perceraian. Akan tetapi jika kematian telah memisahkan keduanya, bagi pihak yang masih hidup bebas untuk menikah lagi (Mat 19:16 Band Roma 7:2).

\section{Perkawinan Kristen Harus Bermeterai Pemberkatan Nikah Kudus}

Suatu perkawinan dinyatakan syah oleh TUHAN jika telah dimeteraikan dengan berkat nikah kudus. Pemberkatan nikah kudus itu tidak dilakukan secara tersembunyi, melainkan secara terbuka dan disaksikan oleh jemaat TUHAN. Pengakuan Pemerintah atas perkawinan Kristen didasarkan pada Surat Keterangan yang dikeluarkan oleh Gereja. Meterai perkawinan yang dikeluarkan oleh Pemerintah berupa Akta Perkawinan.

Tanpa berkat nikah kudus sesungguhnya perkawinan Kristen tidak pernah ada, sekalipun mungkin suatu kehidupan bersama telah dibangun dan generasi baru pun telah dilahirkan. Dengan perkawinan kudus ini Allah akan bebas berkarya atas keluarga Kristen untuk memberkati, melindungi dan menurunkan benih-benih illahi (Kej. 1:28, 29; 2:23, 24). Perlunya pemberkatan nikah Orang yang hidup bersama tanpa pemberkatan nikah berarti mereka hidup dalam perzinahan. Sekalipun mungkin yang bersangkutan sudah melakukannya secara adat atau menikah secara catatan sipil. Mengapa? Sebab Allah sebagai pencipta lembaga perkawinan tidak dihormati dan kepada-Nya tidak dimohon untuk memberkati. Sesuatu yang aneh bukan? Orang yang kawin tetapi tidak menerima pemberkatan nikah kudus akan mengakibatkan hal-hal buruk turun-menurun dalam kehidupan keluarga mereka.

Pemberkatan nikah adalah pemberian otoritas kepada masing-masing maupun kepada keduanya untuk melakukan tanggung jawab rohani, yaitu melakukan tanggung jawab di bumi atas nama dan untuk kemuliaan Allah (Kej 1:28).

\section{HAKEKAT PERKAWINAN KRISTEN}

Sesuatu yang hakiki adalah sesuatu yang sebenarnya, sesuatu yang esensi, yang tidak dapat dipungkiri kenyataannya. Perkawinan Kristen pada hakikatnya ialah penyatuan kembali gambar Allah seutuhnya. Rumusan ini mengandung dua pengertian, yaitu bahwa perkawinan Kristen adalah peristiwa penyatuan kembali. 
Dan penyatuan kembali yang dimaksud ialah penyatuan kembali gambar Allah seutuhnya.

Perkawinan Kristen sebagai penyatuan kembali Perkawinan Kristen disebut sebagai penyatuan kembali karena asal-mulanya manusia itu hanya seorang diri saja, yaitu Adam. Dari yang seorang ini Allah membentuk pasangannya dari dalam dirinya sendiri. Allah mengubah status manusia dari "dia" (Adam) menjadi "mereka", yaitu Adam dan Hawa. Demikian pernyata-an firman-Nya: "Maka Allah menciptakan menusia itu menurut gambar-Nya, menurut gambar Allah diciptakanNya dia; laki-laki dan perempuan diciptakan-Nya mereka." (Kej. 1:27) "Dia" sekarang telah terpisah menjadi "mereka", yaitu laki-laki dan perempuan. "Dia" yang simetris telah menjadi "mereka" yang asimetris. Nah, untuk menjadi simetris kembali Allah menganugerahkan kepada mereka kasih eros. Kasih eros adalah kasih lawan jenis yang membawa mereka bersatu dalam perkawinan. Kasih itulah yang menjadi perekat untuk menyatukan kembali.

Perkawinan Kristen sebagai penyatuan gambar Allah seutuhnya.

Adam disebut gambar Allah karena kepada Adam Allah mengaruniakan kesamaankesamaan keilahian dengan-Nya. Sifat-sifat Allah ada di dalamdirinya. Sebagai gambar Allah Adam sempurna. Kepada Adam Allah mewariskan sifat-sifat "kebapaan"-Nya dan kepada Hawa sifat-sifat "keibuan"-Nya (Yes. 42:15;49:15;66:13). Nyatalah sekarang bahwa masing-masing menjadi tidak lengkap dan tidak sempurna. Untuk menjadi lengkap dan kembali sempurna Allah mempersatukan mereka melalui lembaga perkawinan. Hal ini akan menjadi jelas setelah mereka melahirkan anak-anak. Anak-anak akan melihat gambar Allah itu ada pada ayah dan ibu mereka. Ayah mencerminkan sifat kebapaan Allah dan ibu mencerminkan sifat keibuan Allah. Pengenalan yang benar tentang sifat-sifat ayah dan ibu mereka akan menolong dan memudahkan anak-anak mengenal Allah. Sebagaimana Tuhan Yesus katakan: “... Barangsiapa telah melihat Aku, ia telah melihat Bapa; ..." (Yoh 14:9)

\section{Muatan-Muatan Kebenaran}

Dari pemahaman bahwa perkawinan adalah penyatuan kembali, maka di dalamnya terkandung empat kebenaran. Keempat kebenaran itu menyatakan bahwa perkawinan Kristen proyeknya Allah, bersifat abadi, hiteroseksual-monogami dan kudus.

\section{Perkawinan Kristen Itu Proyeknya Allah}

Pernyataan bahwa manusia itu dibuat tidur nyenyak memberitahukan kepada kita bahwa manusia dalam keadaan pasif. Dalam hal ini Allah tidak memerlukan campur tangan manusia. Seutuhnya dan sepenuhnya semata-mata adalah otoritas Allah sendiri. Manusia menerima apa yang telah Allah perbuat baginya. Hal ini jelas seperti pernyataannya sendiri:'Inilah dia, tulang dari tulangku dan daging dari dagingku, Ia akan dinamai perempuan, sebab dia diambil dari laki-laki."(Kej 2:23). Oleh karena perkawinan itu proyeknya Allah, maka manusia tidak memiliki hak untuk mengubah polanya, apa lagi membubarkannya. 


\section{Perkawinan Kristen Itu Abadi}

Perkawinan adalah tindakan sadar yang dilakukan oleh sepasang anak manusia, yang akan dialami bersama; baik dalam suka maupun dalam duka di sepanjang hayat. Perkawinan bukanlah tindakan coba-coba, tindakan memenuhi kewajiban atau tindakan keterpaksaan. Dari dalam, perkawinan adalah tindakan kepastian yang mengunci mata, telinga dan nafsu kepada pihak lain mana pun. Masing-masing mengkhususkan dirinya bagi pasangannya. Sedangkan dari pihak luar, tidak diijinkan pihak manapun untuk mencoba menggagalkan sebuah perkawinan Kristen. Alkitab tidak pernah menceritakan bahwa Adam dan Hawa bercerai. Bahkan Tuhan Yesus sendiri menyatakan: "Demikianlah mereka bukan lagi dua, melainkan satu.

Karena itu, apa yang telah dipersatukan Allah, tidak boleh diceraikan oleh manusia." (Mat 19:6). Demikian juga nabi Maleakhi: "Sebab Aku membenci perceraian, fitman TUHAN, Allah Israel - juga orang yang menutupi pakaiannya dengan kekerasan, firman TUHAN semesta alam. Maka jagalah dirimu dan janganlah berkhianat."(Mal 2:16) Akan tetapi pada kenyataannya ada keluarga kristen yang bercerai. Mengapa? Tuhan Yesus menyebutnya sebagai adanya ketegaran hati (Mat 19:8).

\section{Perkawinan Kristen Itu Hiteroseksual-Monogami}

Perkawinan Kristen di dalamnya tidak terdapat adanya kemungkinan kawin poligami, poliandri maupun perkawinan sejenis. Sebab yang ada hanya dua orang, yaitu Adam dan Hawa. Tidak ada pihak lain di sekeliling mereka. Allah memperingatkan mereka yang hidupnya tidak tertib dan tidak hormat terhadap perkawinan (Im. 20:13; 1 Kor. 7:2). Kegeraman Allah atas mereka yang tidak tertib terhadap seks dan perkawinan telah ditunjukkan pada murka-Nya atas penduduk Sodom dan Gomora. (Kej. 19)

\section{Perkawinan Kristen itu kudus}

Perkawinan Kristen di dalamnya tidak terdapat adanya kemungkinan perselingkuhan, sebab di sana tidak ada orang ketiga; kecuali hanya Adam dan Hawa. Perselingkuhan adalah pelanggaran terhadap tatanan atau hukum Allah dan karenanya perselingkuhan adalah dosa. Tetapi mengapakah dunia mengenal perceraian, poligami dan juga perselingkuhan? Itu karena ketegaran hati manusia, tetapi sejak semula tidaklah demikian.

Ayat-ayat berikut menolong kita untuk memahami pengertian ini. "...Jadi jagalah dirimu! Dan janganlah orang tidak setia terhadap isteri dari masa mudanya." (Mal. 3:15b) "Hendaklah kamu semua penuh hormat terhadap perkawinan dan janganlah kamu mencemarkan tempat tidur, sebab orang-orang sundal dan pezinah akan dihakimi Allah.” (Ibr. 13:4). Jadi apa yang telah tertulis adalah konsepnya Allah.

Apa yang telah dikonsepkan oleh Allah adalah baik dan sempurna. Hal itu bukan untuk kepentingan Allah, melainkan untuk kepentingan manusia sendiri. Oleh karena itu jika manusia menginginkan hidup perkawinannya baik dan lestari, maka jangan sekali-kali mengutak-atik atau bahkan mengoyak hukum dan rencana Allah. 
Jangan mengganti tatanan Allah dengan tatanan sendiri. Ikutilah jalan-jalan-Nya maka kita akan tetap berada dalam keadaan baik. ${ }^{11}$

\section{HAKEKAT PERNIKAHAN MENURUT ALKTAB}

Hakikat pernikahan merupakan dasar utama yang Allah tetapkan bagi manusia, pertama kepada ciptaan-Nya manusia pertama yaitu Adam, dan dalam kesendiriannya itulah Allah berinisiatif perlunya seorang penolong dan juga menjadi pedamping serta meneruskan keturunan untuk memenuhi bumi. Dalam hakikat pernikahan itu sendiri sebagai suatu ikatan janji (Covenan) yang menjadi konsep yang memainkan peran sentral alam pewahyuan Ilahi. ${ }^{12}$

Salah satu tujuan pernikahan adalah menghasilkan keturunan atau generasi. Memang pada dasarnya yang diharapkan oleh pasangan suami istr adalah buah hati. Demikian keturunan menjadi tujuan dalam pernikahan. Pertanyaannya, keturunan seperti apa yang diharapakan dalam pernikahan? Maleakhi 2:15, menyatakan mengenai keturunan yang berasal dari Allah atau keturunan yang dikehendaki Allah. Dalam hal ini bukan hanya keturunan secara daging atau lahiriah. Bukan sekedar keturunan yang terjadi oleh nafsu manusia saja. Tetapi dalam hal ini juga ketrunan Ilahi yaitu anak-anak rohani.

Pernikahan adalah suatu lembaga yang ditetapkan Allah bagi manusia sesuai dengan kebutuhannya. Perhatikan Frase dalam "Tidak baik, kalau manusia itu seorang diri saja. Aku akan menjadikan penolong baginya, yang sepadan dengan dia" (Kejadian 2:18). Saat laki-laki (ha adam) "seorang diri saja" maka Allah menyatakan bahwa keadaan ini "tidak baik". Jadi Allah memutuskan untuk menciptakan "ezer kenegdo" atau "seorang penolong". Kata Ibrani "ezer" yang diterjemahkan dengan "penolong" berarti "sesuai dengan" atau "sama dengan". Jadi secara harfiah "seorang penolong" berarti "penolong yang sepadan atau seorang yang sepadan dengannya". Dengan demikian jelaslah bahwa Allah sendiri yang menetapkan lembaga Pernikahan dan memberkatinya.

Ketetapan Tuhan ini tidak pernah berubah dan ini berlaku "sejak semula" bagi semua orang, bukan hanya bagi orang-orang Kristen saja. Matius mencatat perkataan Kristus demikian, "Jawab Yesus: "Tidakkah kamu baca, bahwa Ia yang menciptakan manusia sejak semula (ap'arches) menjadikan mereka laki-laki dan perempuan?" (Matius 19:4). Kata Yunani "ap'arches" atau "sejak semula" yang disebutkan Yesus dalam Matius 19:4, pastilah merujuk pada Kejadian Pasal 2, karena kalimat selanjutnya "Dan firman-Nya: Sebab itu laki-laki akan meninggalkan ayah dan ibunya dan bersatu dengan isterinya, sehingga keduanya itu menjadi satu daging", yang diucapkan Yesus dalam ayat 5 adalah kutipan dari Kejadian 2:24; merupakan penggenapan janji. Pernikahan adalah satu-satunya lembaga sosial yang ditetapkan Allah sebelum kejatuhan manusia dalam dosa (Kejadian 2:24; Banding Kejadian 1:28). Karena itu pernikahan wajib dihormati oleh semua orang (Ibrani 13:4). Allah telah menetapkan pernikahan dari sejak semula, baik untuk orang-orang Kristen maupun untuk orang-orang bukan Kristen. Dan Allah adalah saksi dari seluruh pernikahan, baik diundang maupun tidak. Meskipun bentuk dan tatacara bervariasi dalam setiap budaya dan setiap generasi tetapi esensinya tetap sama dari "sejak semula" bahwa pernikahan merupakan satu peristiwa sakral tidak peduli pasangan

\footnotetext{
${ }^{11}$ Bidi Asali, Eksposisi Kitab 5 : 22-33

12 Derek Prince, Pernikahan Ikatan Kudus, (Batu: Yayasan Pekabaran Injil, 1993 ), 32
} 
tersebut mengakuinya ataupun tidak. Sebuah keluarga dimulai ketika seorang pria dan seorang wanita memutuskan untuk menikah dan hidup bersama (Kejadian 2:24).

Ketetapan Tuhan ini tidak pernah berubah dan ini berlaku "sejak semula" bagi semua orang, bukan hanya bagi orang-orang Kristen saja. Matius mencatat perkataan Kristus demikian, "Jawab Yesus: "Tidakkah kamu baca, bahwa Ia yang menciptakan manusia sejak semula (ap'arches) menjadikan mereka laki-laki dan perempuan?" (Matius 19:4). Kata Yunani "ap'arches" atau "sejak semula" yang disebutkan Yesus dalam Matius 19:4, pastilah merujuk pada Kejadian Pasal 2, karena kalimat selanjutnya "Dan firman-Nya: Sebab itu laki-laki akan meninggalkan ayah dan ibunya dan bersatu dengan isterinya, sehingga keduanya itu menjadi satu daging dalam penenuhan

janji. Pernikahan adalah satu-satunya lembaga sosial yang ditetapkan Allah sebelum kejatuhan manusia dalam dosa (Kejadian 2:24; Banding Kejadian 1:28). Karena itu pernikahan wajib dihormati oleh semua orang (Ibrani 13:4). Allah telah menetapkan pernikahan dari sejak semula, baik untuk orang-orang Kristen maupun untuk orangorang bukan Kristen. Dan Allah adalah saksi dari seluruh pernikahan, baik diundang maupun tidak. Meskipun bentuk dan tatacara bervariasi dalam setiap budaya dan setiap generasi tetapi esensinya tetap sama dari "sejak semula" bahwa pernikahan merupakan satu peristiwa sakral tidak peduli pasangan tersebut mengakuinya ataupun tidak. Sebuah keluarga dimulai ketika seorang pria dan seorang wanita memutuskan untuk menikah dan hidup bersama (Kejadian 2:24).

Memahami pengertian tentang perkawinan dan hakikat perkawinan layak dan perlu dimiliki oleh setiap orang. Pernikahan atau perkawinan memiliki tujuan adalah membentuk keluarga bahagia ,bahkan tidak hanya bahagia saja namun juga kekal. Perencanaan pernikahan merupakan inisiatif Allah. Allah memprakasai pernikahan itu. Allah memprakasai pernikahan pada permulaan sejarah umat manusia. Manusia sendiri tidak pernah turut pernah turut merencanakannya, sesungguhnya manusia tidak akan mengerti apa pernikahan itu. ${ }^{13}$

Adapun esensi dari pernikahan seperti yang dirancang dan ditetapkan Allah sangatlah penting bagi kelanggengan hubungan pernikahan. Karena itu kita akan memperhatikan pengajaran Tuhan Yesus mengenai pernikahan dalam Matius 19:410 dan pasal-pasal pararel lainnya. Pertama-tama kita akan melihat definisi Pernikahan dan kemudian memperhatikan esensi dari pernikahan. Pernikahan dapat didefisinisikan sebagai berikut: "pernikahan merupakan hubungan eksklusif antara satu laki-laki dan satu perempuan, dimana keduanya menjadi "satu daging", disatukan secara fisik, emosional, intelektual, dan spiritual; dijamin melalui sumpah sakral dan ikatan perjanjian serta dimaksudkan untuk seumur hidup". Definisi ini didasarkan pada pernyataan Alkitab dalam Kejadian 1:24; Matius 19:5; Markus 10:7; Efesus 5:31. Berdasarkan definisi tersebut, berikut ini lima esensi pernikahan Kristen.

Rahasia utamanya agaknya terletak pada masalah pilihan yang dibuat baik sesuatu yang mendasar dapat dipertanggung-jawab dalam setiap pernikahan sebab ini bukanlah jalinan kasih yang hanya sementara melainkan seumur hidup. ${ }^{14}$ Memang ini adalah hal yang serius yang harus dijalani manusia, dalam menjalaninya.

\footnotetext{
${ }^{13}$ Dereks Prince, Jodoh Pilihan Tuhan ..., 64

${ }^{14}$ Ken Nerburn, “Kebenaran yang hakiki, “ ( Interaksara , 1999), 75
} 


\section{LANDASAN HISTORIS PERNIKAHAN KRISTEN}

Pernikahan merupakan inisiatif Allah dan Allah sendirilah "Desainer " yang telah mendesain, pernikahan sebagai sesuatu yang sagat indah. pernikahan merupakan satu lembaga ciptaan Allah yang diberikan kepada manusia sebagai pengelola bumi ini, dan diberi wewenang ini menggunakannya, dan melalui pernikahan akan adanya keturunan dan menciptakan suatu keluarga baru. Sejak Allah menciptakan manusia adalah pengelola, maka Adam sebagai manusia pertama memerlukan teman, sekaligus pendamping hidup dan memberi keturunan.

\section{Kehidupan Pernikahan Menurut Perjanjian Lama}

Dalam perjanjian Lama dapat dibedakan dua macam keterangan dan kesaksian tentang perkawinan.. Keterangan mengenai lembaga perkawinan . mecam-macam peraturan dan ketentuan tentang perkawinan dan ketentuan perkawinan, jadi terlebih dahulu hukum perkawinan ada juga keterangan -keterangan

Kehidupan perkawinan sejak Perjanjian Lama telah dilaksanakan menurut kaidah yang berlaku masa itu. Tetapi pemahaman arti pernikahan pada masa perjanjian lama dan gereja di Inggris memberikan definisi pernikahan sebagai berikut: Pernikahan adalah karunia, sehingga suami istri dapat saling menghibur, saling menolong satu dengan yang lain, hidup setia bersama dalam kekurangan dan kekayaan, dalam suka dan duka, ia adalah karunia, sehingga dengan kesenangan dan kelembutan mereka dapat saling mengenal dalam kasih, dan melalui hubungan tubuh mereka dapat menguatkan hati dan hidup mereka. Ia adalah karunia, sehingga dapat empunyai anak-anak dan diberkati dalam membesarkan mereka ${ }^{15}$

Sedangkan menurut J.H. Olthuis, pernikahan adalah penyatuan yang mutual, eksklusif, seumur hidup, dan satu daging antara suami istri yang bercirikan troth. ${ }^{16}$ Dalam Perjanjian Baru bahasa Yunani ,kata menikah bisa berarti diberikan atau bisa berarti diambil dalam pernikahan; tak ada satu pun kata yang menyiratkan makna perjanjian untuk bersama antara dua pihak yang setara. Dalam bahasa Ibrani terdapat lebih dari lima kata yang berbeda yang digunakan untuk menunjukkan hubungan yang dilakukan antara laki-laki dan perempuan mulai dari ba'al ( menguasai atau memiliki), kemudian ownah (hak-hak suami -istri ) hingga halal ( bersinar, memuji atau berharga - Mazmur 78) dan nasa (mengangkat atau memikul). Kebanyakan pasangan hanya merujuk yang lain. Menariknya kebanyakan pernikahan pada masa Alkitab adalah sekuler,sebagaimana pernikahan-pernikahan itu masa kii, Hanya orang-orang yang religious yang meminta berkah rabi dalam perayaan .

Dalam kepercayaan orang Yahudi, pernikahan sangatlah penting untuk memenuhi perintah Tuhan. Perintah tersebut tidak hanya didasarkan atas perintah yang terkenal untuk "berkembang biaklah dan bertambah banyaklah " (Kej. 1:22), tetapi juga atas frase, "tidak baik kalau manusia itu seorang diri saja; akau akan menjadikan penolong (ayzer $=$ orang yang memelihara) baginya...dst. Sebab itu seorang laki-laki akan meninggalkan ayahnya dan ibunya dan bersatu dengan istrinya, sehingga keduanya menjadi satu kita Talmud menyatakan dengan sedikit lebih ringkas;

"Dia yang tidak mempunyai istri bukanlah laki-laki" (Yebamot 63a). Nilai pernikahan bagi seorang laki-laki sangat sering ditekankan di dalam

\footnotetext{
${ }^{15}$ Daniel Tanusaputra, “Teologi Pernikahan \& Keluarga " (Malang: SAAT, 2005 ), 73

${ }^{16}$ Trot adalah istilah bahasa Inggris kuno untuk kesetiaan
} 
naskah-naskah Yahudi (ini tidak mengejutkan karena semua naskah ditulis oleh para sarjana laki-laki), tetapi Talmud juga benyak memberikan perhatian pada hak-hak para istri - dari yang bersifat ekonomi hingga seksual. Seorang laki-laki diharapkan mengasihi istrinya seperti dia mengasihi dirinya sendiri dan untuk menghormatinya lebih dari dia menghormati dirinya sendiri (Yebamot $62 \mathrm{~b}){ }^{17}$

Biasanya orang tua lelaki yang memilih calon istri puteranya dan mengatur pernikahan, seperti dilakukan Hagar dan untuk Ismail (Kej. 21:21) dan Yehuda untuk Er (Kej. 38:6). Kadang-kadang si pemuda yang memilih, dan orang tuanya membicarakan pernikahan, dalam hal Sikhem (Kej. 34:4, 8) dan Simson (Hak. 14:2). Jarang seorang Pemuda menikah di luar kehendak orang tuanya, seperti yang dilakukan Esau (Kej. 26: 34-35). 5 Hal ini mungkin dikarenakan budaya pernikahan orang Yahudi, seperti sebagian besar budaya lain, diatur oleh para orang tua, biasanya di dalam keluarga sendiri yang lebih luas atau bila hubungan dengan keluarga lain dianggap menguntungkan dan walaupun harus dipastikan bahwa pasangan muda itu cocok, cinta tidak dinggap penting. Anak-anak perempuan dan laki-laki ditunangkan pada saat mencapai pubertas dan menikah pada tahun berikutnya. Didukung lagi, adakalanya orang tua perempuan yang memilih calon suami yang pantas seperti dilakukan Naomi (Rut. $3: 1-2)$ dan Saul (1Sam. $18: 21) .{ }^{18}$

Pada saat sebelum menikah, seorang wanita berada di bawah otoritas ayahnya, dan setelah wanita tersebut menikah, ia berada di bawah otoritas suminya. Seorang suami dipanggil ba'al atau "tuan" oleh istrinya, karena ia adalah ba'al dari sebuah keluarga atau field (Kel. 21:3, 22; 2Sam. 11:26; Ptr. 12:4 dst). Seorang wanita yang telah menikah oleh karena itu menjadi "milik" ba'alnya (Kej. 20:3; Ul. 22:22). Sesungguhnya 'mengawini seorang wanita' diungkapkan dengan kata ba'al, yang memiliki maksud akar kata ' menjadikan tuan' (Ul. 21:13; 24:1).[6] Dalam budaya patriakhal seorang perempuan tinggal di rumah keluarganya sebagai tempat tinggalnya. Perempuan yang menikah akan membentuk rumah bersama dengan suami dan anak-anaknya, dan seorang laki-laki harus menikah dengan perempuan yang masih satu suku bukan dengan perempuan asing bahkan secara endogamy agar ibadah kepada Tuhan; agar ibadah kepada Tuhan tidak tercemar (Kej. 24:4; 28:1-2).

Istri harus menyiapkan makanan, membakar roti, mencuci, memasak, menyusui anak-anak. Mengatur tempat tidur suami, dan pada waktu luangnya mengola bulu domba dengan memintal dan menenun. Istri wajib dan mutlak taat kepada suaminya, dan suami menjadi tuanya ( pada kenyataanya suami disebu rab.dan kenyataannya menjadi kewajiban keagamaan.

Dalam pernikahan orang Israel juga dikenal istilah Mohar, yakni uang penganti dari pihak laki-laki kepada pihak perempuan, dan itu memateraikan perjanjian yang mengikat kedua pihak. Mohar atau Mahar bisa berupa uang, permata, properti atau apapun yang dianggap bernilai. Oleh kedua keluarga. Sebagaimana yang mungkin dikira, tata aturan di sekitar hari pernikahan Yahudi agak rumit. Tak seorang pun boleh menikah pada saat pesta supaya tidak mengacaukan perayaan-perayaan atau menganggu ketenangan hari Sabat. Seorang perawan melaksanakan pernikahan pada setiap Rabu sore sehingga memungkinkan suaminya mengajukan keberatan secara

\footnotetext{
${ }^{17}$ Maggy Whitehouse..., 94

${ }^{18}$ Maggy Whitehouse ..., 155
} 
formal ke pengadilan Sanhedrin - yang digelar setiap Kamis - bila pada malam pernikahan diri sang suami mendapati ketidakmurnian mempelainya. Para janda melaksanakan pernikahan pada setiap kamis ketika tidak ada keberatan yang sama sahnya terhadap mereka. Mempelai perempuan mengenakan kerudung perkawainan - wajah dan rambutnya harus tertutup untuk upacara yang sesungguhnya - dan terdapat entah sebuah kerudung yang dijereng menutupi pasangan tersebut atau sebuah tenda yang didirikan agar pernikahan terjadi di dalam. Saat ini hal itu dikenal sebagai sebuah chupah - sebuah kelambu di atas empat batang galah di mana pernikahan berlangsung di bawahnya. Chupah yang menutupi kadang-kadang bisa merupakan talit atau syal doa seorang laki-laki.

Pada masa kuno dan mungkin masih berlangsung pada zaman Yesus, pasangan pengantin memakai mahkota, sebagaimana masih dipergunakan dalam perkawinanperkawinan Yunani ortodoks. Cabang pohon palma dan cabang pohon mirtus diangkut ke depan mereka dan butir-butir padi-padian atau uang dilemparkan sebagai konfeti. Prosesi diawali dengan musik dimana semua orang yang dilewatinya diharapkan bergabung - sebagai sebuah kewajiban religius. Para gadis yang membawa lampu di atas tongkat layaknya obor (gadis-gadis yang bijaksana dan gadis-gadis yang bodoh dalam Matius 25:1) memandu calon pengantin laki-laki menemui mempelai perempuannya dan perayaan dilanjutkan dengan pesta-pesta yang akan berlangsung selama satu minggu penuh. Kedua mempelai diharapkan bisa menjaga diri mereka sendiri selama seminggu itu untuk melakukan persetubuhan sebanyak mungkin - karena itu diceritakan dalam Kitab Kejadian ketika Yakub terkalabui sehingga menikahi Lea bukannya Rachel yang dicintainya, anak-anak perempuan ayah Rachel memberitahu Yakub untuk "mengenapi tujuh hari perkawinannya"(Kej. 29:27) sebelum sang ayah memberikan Rachel kepada Yakub menjadi mempelai perempuannya. ${ }^{19}$

\section{Teologi Pernikahan Dalam Perjanjian Lama}

Membahas tentang pernikahan memiliki banyak pengertian karena setiap orang memiliki sudut pandang yang berbeda-beda dalam memaknainya. Sebagian orang mengaitkan pernikahan dengan "berada dalam cinta". Kata pernikahan menyebabkan orang lain memikirkan suatu pesta pernikahan. Pemerintahan juga memiliki pengertian pernikahan yang dinyatakan dalam hukum mengenai pernikahan. Hukumhukum ini berkaitan dengan masalah-masalah seperti usia, keluarga, harta dan perceraian. Hukum-hukum manusia bermanfaat, tetapi gagasan tentang pernikahan tidak berasal dari manusia melainkan dari si Pencipta, itu sebabnya untuk memahami apa yang Allah nyatakan mengenai pernikahan, selayaknya setiap orang melihat dari kebenaran Alkitab apa yang Alkitab nyatakan mengenai pernikahan. Maka penulis akan menjelaskan terlebih dahulu tinjauan umum pernikahan dalam Perjanjian Lama.

Pernikahan Sebagai Lembaga Pertama Yang Diciptakan Allah. "Pada mulanya Allah menciptakan langit dan bumi" (Kejadian 1:1). Dia menciptakan daratan dan lautan, matahari dan bulan, tumbuhan dan hewan, dan pada mulanya, Allah menciptakan laki-laki dan perempuan serta menyatukan mereka bersama dalam pernikahan (Kejadian 1:27-28). Pernikahan merupakan gagasan dari Allah, itu sebabnya setiap orang percaya selaknya memakai Alkitab untuk menjelaskan arti

${ }^{19}$ Idem 
pernikahan dan keluarga. Tuhan Allah berfirman: "Tidak baik, kalau manusia itu seorang diri saja. Aku akan menjadikan penolong baginya, yang sepadan dengan dia." Kejadian 2:18

Pernyataan ini mengenai sifat dasar manusia yang memiliki keinginan berteman: "Tidak baik, kalau manusia itu seorang diri saja" ia tidak diciptakan sebagai mahluk yang sama sekali tidak memerlukan orang lain, tetapi sebagai mahluk yang berpasangan. Jawaban Allah terhadap kesendirian manusia ialah dengan menciptakan "seorang penolong" yakni "pasangan" yang sepadan dengan Adam. Allah melihat kesedirian Adam merupakan suatu hal yang "tidak baik" maka dalam hal ini Allah yang memiliki inisiatif memberikan seorang pendamping bagi Adam. Adam tidak menemukan "seorang penolong yang sepadan baginya" (Kejadian 2:19-20), di sini bisa dilihat bahwa Allah menciptakan Adam sebagai mahluk yang membutuhkan seorang pasangan.

Kemudian Allah menciptakan (harafiah 'membangun') perempuan dari tulang rusuk Adam dan membawa kepadanya (Kejadian 2:21-22). Setelah perempuan diciptakan, Allah membawa perempuan itu kepada Adam. Allah "membawa" perempuan kepada Adam menunjukkan keaktifan dari pihak Allah. Ini sesuai dengan Kejadian 2:21 ketika Adam tertidur (pasif) dan Allah (aktif) menyediakan pasangan bagi Adam. Lalu Adam berkata: "Inilah dia, tulang dari tulangku dan daging dari dagingku. Ia akan dinamai perempuan, sebab ia diambil dari laki-laki" (Kejadian 2:23) Pernyataan Adam akan keberadaan perempuan menunjukkan betapa Adam mendambakan pasangan hidup. Maka dalam Perjanjian Lama, pernikahan merupakan lembaga pertama yang didirikan oleh Allah. Allah yang merancang pernikahan, Allah juga yang mempersatukan Adam dan Hawa sebagai satu keluarga.

Setelah manusia jatuh dalam dosa, pernikahan menjadi tidak lagi sesuai seperti apa yang Allah rancangkan pada mulanya. Dalam kejadian pasal 3 dan keseluruhan kitab-kitab Perjanjian Lama menunjukkan kedaan-keadaan pernikahan yang tidak lagi adanya kesatuan, seperti poligami dan perceraian.

\section{Kitab Kejadian 1 Dan Kejadian 2}

Kitab Kejadian pasal 1 dan 2 terbagi dalam dua sumber penulisan, yakni: 12:4a berasal dari sumber P. Di situ diceritakan tahap-tahap kejadian alam semesta dan isinya, yang semuanya terjadi karena firman Allah yang berkuasa. Kejadianmula itu mencapai puncaknya dengan diciptakannya manusia laki-laki dan perempuan sekaligus. Akan tetapi di dalam pasal 2: 4b-25 berasal dari sumber Y, di mana menurut sumber $\mathrm{Y}$ yang mula-mula dijadikan adalah manusia laki-laki sedangkan manusia perempuan dijadikan sesudah itu. Dari kedua sumber yang berbeda ini, sebenarnya mempunyai pesan masing-masing tentang penciptaan lakilaki dan perempuan Sumber $Y$ ingin menjelaskan kepada pembacanya bagaimana keadaan manusia itu sebelum dan sesudah mereka dicitakan, kekurangan dan kelebihan masing-masing sebelum bertemu (Adam dan Hawa) seperti yang dikatakan "Tidak baik, kalau manusia itu seorang diri saja. Aku akan menjadikan penolong baginya, yang sepadan dengan dia (Kej. 2:18).

Jadi dapat kita simpulkan bahwa pesan teologis yang hendak disampaikan oleh penulis $\mathrm{Y}$, di mana pertemuan antara laki-laki dan perempuan (Adam dan Hawa) itu adalah inisiatif dari Allah sendiri. Allah yang berkehendak agar manusia itu memiliki (ezer) penolong yang (neged) yang artinya sepedan atau seimbang walau keduanya 
tidak sama. Pernikahan itu adalah kehendak dari Allah sendiri, yang menginginkan agar manusia ciptaan-Nya itu tidak merasa asing dan kesepian di tengah-tengah ciptaan-Nya yang lain, karena dengan memberikan seorang penolong yang sepadan.

Allah tahu yang terbaik bagi manusia itu. Allah tidak meberikan penolong yang di atas dan di bawah kuasa seorang laki-laki, tetapi Ia memberikan yang sepadan dengannya sebagai manusia ciptaan Allah. Artinya perempuan diciptakan sebagai mitra yang sejajar dengan laki-laki. Penolong yang sepadan dengan dia, tidak mungkin berarti pembantu. Yang menarik dari sumber Y dalam Kej. 2 adalah dalam ayat 24 yang mengatakan: Laki-laki akan meninggalkan ibu-bapaknya dan bersatu dengan istrinya sehingga keduanya menjadi sedaging, yaitu kesatuan yang fana. Ikatan suami istri lebih kuat dari ikatan ayah-anak di dalam marga, fam dan sebagainya. ${ }^{20}$

Fokus utama pada aspek "menyatu" dari hubungan pernikahan

dan seksualaitas itu sendiri sebagai ekspresi kasih.Dari sumber P, cerita penciptaan manusia dibuat dalam versi yang berbeda dan sangat sistematika, yakni dalam Kej. 1:26-31. Penciptaan manusia ini juga merupakan inisiatif dari Allah sendiri. Manusia laki-laki dan perempuan diciptakan Allah, karena Ia mempunyai amanat khusus bagi mansia tersebut. Allah di dalam inisiatif dan amanat-nya tersebut memberkati mereka, sebab apa yang Ia ciptakan amal baik. Kesimpulan telogisnya adalah di mana pernikahan itu merupakan amanat dari Allah sendiri bagi manusia, yang tujuannya amat baik menurut Allah, sebab di dalam amanat-Nya, Allah juga memberkati pernikahan manusia. Keduanya diberkati dan diberikan kuasa.

Jadi pernikahan menurut kitab Kejadian 1 dan 2 merupakan inisiatif dari Allah sendiri, karena Allah memiliki amanat khusus dalam dalam pernikahan itu sebab Allah memandang itu baik sehingga Ia memberkati pernikahan. C. Barth mengatakan bahwa Kejadian 1 dan 2 sepakat melihat manusia dalam bentuk laki-laki dan perempuan sebagai mitra yang setingkat-sederajat yang hendak saling menolong, bukan dalam keluarga saja, melainkan juga dalam masyarakat luas. Demikianlah manusia menurut rencana Allah.

\section{Kitab Ulangan}

Umat Israel merupakan umat yang khusus, banyak hal yang telah dilakukan oleh Allah kepada bangsa ini, terjadi masa di mana bangsa ini terpecah menjadi dua kerajaan utara ibukota Yerusalem dan Kerajaan selatan ibu kota Yehuda. Israel telah musnah, maka tinggal Israel selatan yang harus dipertaruhkan, sebab pada saat itu Yerusalem sedang menghadapi masa yang sulit, yaitu ancaman kekafiran dan penyembahan berhala yang dipimpin oleh raja Manasse. Para penulis Kitab Ulangan merencanakan perlunya Reformasi dan pembaharuan hidup. ${ }^{21}$

Reformasi ini juga menyangkut hal-hal yang berhubungan dengan pernikahan, seperti teks berikut ini yang mengatakan "Janganlah juga engkau kawin-mengawin dengan mereka: anakmu perempuan janganlah kauberikan kepada anak laki-laki mereka, ataupun anak perempuan mereka jangan kauambil bagi anakmu laki-laki” (U1. 7:3). Larangan untuk mengambil istri di luar dari bangsa Israel. Larangan ini hendak menekankan bahwa adat dan kekayaan kaum kafir mudah menjadi jerat (7:16, 25), sehingga umat itu melupakan utang-budinya terhadap Tuhan serta

\footnotetext{
${ }^{20}$ Dr.Christoph Bart, Teologi PL 1, (Jakarta : BPK Gunng Mulia , 2002), 38-39

${ }^{21}$ S.Wismoady Wahono, .Di sini kutemukan, ( Jakarta : BPK Gunung Mulia , 2004), 69
} 
meninggalkan ketaatannya. Teks-teks ini tentu di latar belakangi pada masa penulisan pertama dari $\mathrm{D}$, mereka sedang diancam oleh sinkretisme di utara.

Perkembangan selanjutnya dalam pasal 21:11-14 adalah menarik bahwa rasa curiga terhadap pernikahan dengan wanita asing, seperti yang nampak pada periode post-pembuangan (Ezr. 9:2; 10:2; 10:10; Neh. 13:27) tidak kelihatan dalam perikop ini. Sebagaimana ditekankan dalam kitab Ulangan, ciri-ciri keimanan Israel ditentukan oleh kehadiran kaum laki-laki (bapa dan suami) di hari-hari raya (Ul. 16:16), dan oleh kebiasaan bahwa ajaran yang diterima di situ oleh kaum laki-laki, diteruskan kepada anggota-anggota rumahtangga masing-masing, (Ul. 6:20). Peranan umat itu dalam pemeliharaan kemurniaan agama digaris-bawahi juga oleh mazhab Ulangan dalam menekankan pemusatan ibadat di Bait Suci Yerusalem (12:12, 18; $16: 11,14)$. Selama struktur keagamaan yang demikian dapat diperahankan dalam keadaan utuh, pernikahan dengan wanita asing yang berasal dari lingkungan lain, tidak dianggap mengandung unsur bahaya.

Karena dengan demikian, faktor utama yang menentukan iman anak-anak bukanlah ibu, melainkan jemaat.Teks -teks iman anak- anak bukanlah ibu, melainkan jemaat. Teks-teks di atas yang mengatur tentang pernikahan harus dilihat sebagai usaha para penulis Kitab Ulangan yang berusaha menonjolkan keterpilihan dan kekhususan haruslah bangsa Israel sebagai umat Allah. Kepada Allah dan sajalah bangsa

\section{Kitab Imamat 18:1-30 Dan 20:1-27}

Dengan ringkas, tujuan dari kitab Imamat adalah memeperlihatkan kepada umat Israel cara bagaimana seharusnya mereka hidup sebagai umat yang kudus, yaitu sebagai umat yang dengannya Tuhan masuk hubungan perjanjian dan yang dipilih serta dipanggil untuk melayani Dia. Hukum-hukum asasi yang terdapat dalam kitab ini terlebih-lebih mengenai ibadah, kekudusan, kenajisan, perbedaan antara yang haram dan yang halal, dan kelakuan etis dalam kehidupan sehari-hari. Dan hukumhukum itu dikumpulkan supaya umat Israel tetap berhubungan baik dengan Tuhan dan mengadakan pendamaian juka mereka bersalah. ${ }^{22}$ Peraturan-peraturan yang sangat ketat, terutama kita lihat dalam kitab Imamat pasal 18:1-30 dan 20:1-27 (yang di dalamnya terdapat paraturan-praturan atau hukum-hukum yang mengatur tentang pernikahan).

Orang-orang Israel diperingatkan secara keras supaya mereka jangan menjadi serupa dengan cara kehidupan orang-orang asing, sama seperti orang-orang Mesir dan Kanaan. Mereka harus menjauhkan dirinya sendiri dari kebiasaan yang tidak sesuai dengan kehendak Tuhan. Jika tidak, maka mereka kehilangan makna dan perannya dalam rencana Tuhan itu. Ayat 7-8 (pasal 18:1-30) berisi suatu daftar hukum yang sangat kuno, pada saat keluarga-keluarga Israel hidup dalam perkemahan-perkemahan, yang ingin menekankan bahwa hubungan seksual dilarang di antara kerabat-kerabat yang dekat, dan orang harus menghormati baik perkawinan maupun kemurniaan anak-anak dara yang tinggal dalam keluarga besar itu. Hukumhukum lain, yang melarang bermacam-macam hubungan seksual yang tidak normal, ditambah dalam ayat 19-23, mungkin dalam beberapa tahap. Hubungan-hubungan itu termasuk hubungan dengan perempuan pada waktu camar kainnya yang menajiskan,

\footnotetext{
${ }^{22}$ Robert M.Peterson, Tafsiran Kitab Imamat, (Jakarta : BPK Gunung Mulia, 2008), 14
} 
zinah, hubungan homoseks serta hubungan dengan binatang, karena perbuatanperbuatan demikian bersifat keji dan menajiskan orang, dan kekudusan nama Allah. ${ }^{23}$

Jadi pernikahan menurut Kitab Imamat, berkaitan erat dengan hukum-hukum dan peraturan-peraturan yang sangat menekankan keteraturan dan kekudusan Allah. Pernikahan diatur dalam hukum dan peraturan di mana tujuannya adalah menjaga kekudusan hidup dan pernikahan seperti yang dikendaki oleh Allah. Sebab pernikahan adalah kudus.

\section{Kitab Ezra Dan Nehemia}

Mulai zaman Ezra dan selanjutnya maka ke- Yahudi-an manjadi agama hukum. Kesalehan sama dengan ketekunan untuk mempelajari hukum-hukum agama dan menaatinya. Nehemia menegakkan kembali imamat orang Lewi, persembahan persepuluhan (Neh. 13:10-14), memberlakukan hari Sabat (Neh. 13:15-22) dan melarang perkawinan campuran (Neh. 13:23-27).

Sikap menetang perkawinan campur seperti yang terdapat dalam Ezra 9:2 yang mengatakan "Karena mereka telah mengambil isteri dari antara anak perempuan orang-orang itu untuk diri sendiri dan untuk anak-anak mereka, sehingga bercampurlah benih yang kudus dengan penduduk negeri, bahkan para pemuka dan penguasalah yang lebih dahulu melakukan perbuatan tidak setia itu", ayat ini mengambarkan bahwa ketika kehidupan relasi antara mereka dengan Allah rusak, maka status mereka sebagai umat pilihan Allah akan hilang. ${ }^{24}$ dan yang terdapat dalam Neh. 13:23-27. Jadi perkawinan campur menurut Ezra dan Nehemia dianggap sebagai ancaman bagi kelangsungan hidup kudus bangsa itu. Jadi pernikahan dalam kitab Ezra dan Nehemia adalah kembali kepada hukum-hukum dan peraturanperaturan ke Yahudi-an, demi kekudusan sebuah bangsa. Akan tetapi sikap eksklusifisme seperti ini ditantang oleh universalisme Deutero-Yesaya, Trito-Yesaya, Yunus dan Rut. Keempat kitab yang disebutkan terakhir ini ditulis segera setelah masa Ezra dan Nehemia, untuk mengembalikan Israel kepada panggilannya yang semula: menjadi berkat bagi bangsa-bangsa di dunia. ${ }^{25}$

- Dari penjelasan di atas dapatlah kita mengambil kesimpulan teologis serta relevansi dari pernikahan menurut Perjanjian Lama, bahwa: Pernikahan itu adalah inisiatif dari Allah sendiri, karena Allah memiliki amanat khusus dalam pernikahan itu sebab Allah memandang itu baik sehingga ia memberkati pernikahan tersebut.

- Rancangan Allah bagi pernikahan adalah Monogami. Tapi poligami dibiarkan sejak zaman Lamekh (Kej. 4:19) dan tidak dilarang dalam Alkitab. Namun poligami secara jelas menimbulkan ketegangan (Ul. 21:15), kesukarankesukaran, dan sering menimbulkan dosa, misalnya Abraham (Kej. 21); Gideon (Hak. 8:29-9:57); Daud (2 Sam. 11:13); Salomo "Doyan seks dan penyembah berhala" (1 Rj. 11:1-8), terjadi permusuhan di dalam rumah tangga (1 Sam. 1:6; bnd. Im. 18:18). Poligami jelas diperbolehkan pada zaman Alkitab, hal ini dikarenakan anak sangat penting dalam kelanjutan nama keluarga, maka istri yang mandul memperbolehkan suaminya untuk berpologami. Meskipun demikian,' itu bukan merupakan sesuatu yang biasa

\footnotetext{
${ }^{23}$ Robert M.Peterson, Tafsiran Kitab Imamat..., 14

${ }^{24}$ F.Charles Fensham, The Book of Ezra and Nehemia, ( Grand Rapids, 1991), 125

${ }^{25}$ Ibid., 261
} 
terjadi. Secara formal dilarang bagi orang-orang Yahudi Ashkenazi sampai abad kedua belas. Tidak ada peraturan demikian bagi orang-orang Yahudi Sephardi sehingga, secara teknis, bila mereka tingga di tempat-tempat di mana poligami diperbolehkan, para laki-laki Yahudi Sephardi masih boleh memiliki lebih dari satu istri'. Dalam PB Yesus (Mat. 19:4) dan Rasul Paulus (Ef. 5:31; 1 Kor. 7:2; 1 Tim. 3:2, 12; Tit. 1:6) menegaskan kembali konsep monogami itu. Model tersebut ditekankan dengan fakta bahwa gambaran Pernikahan sebagaimana digunakan dalam Alkitab adalah model untuk hubungan Yahwe dengan Israel dan antara Kristus dan Gereja

- Allah merancang pernikahan sebagai penyatuan heteroseksual. Ia menyediakan Adam "dengan penolong yang kebalikan dari dirinya dan bukan laki-laki yang lain.tetapi dengan 'isshah' perempuan itu." Ini adalah penyatuan untuk mana prokreasi dirancang. Maka homoseksualitas adalah penyimpangan dari maksud asli Allah bagi seksualitas manusia. PB berbicara secara negatif mengenai tindakan

homoseksual

(1Kor. 6:9; 1 Tim. 1:1:10). Konteks ayat- ayat ini adalah imoralitas orang kafir.

- $\quad$ Pernikahan adalah kudus, karena itu kita harus bersikap kritis terhadap adat kebudayaan (baik dari secara intern maupun ekstern), jangan sampai adat dan kebudayaan yang "tidak baik" menghilangkan nilai-nilai kekristenan. Akan tetapi kebudayaan yang baik harus tetap dipelihara.

- Pernikahan tidak hanya menyangkut masalah cinta dan suka tetapi pernikahan sangat berhubungan dengan hukum-hukum dan peraturan yang bersifat kultus, di mana tujuannya adalah untuk menjaga kekudusan sebuah bangsa, nama baik lembaga, masyarakat dan pernikahan itu sendiri. Pernikahan tidak hanya menyangkut kedua pihak laki-laki dan perempuan, tetapi berhubungan dengan orang lain juga.

- Pernikahan berbicara soal keteraturan dan kekudusan Allah.

- $\quad$ Pernikahan campur diijinkan asalkan dapat bersama menjadi satu iman kepada Allah. Sikap eksklusif dalam adat atau budaya pernikahan akan menghilangkan panggilan kita untuk menjadi berkat bagi adat dan budaya.

\section{Kehidupan Pernikahan Menurut Perjanjian Baru}

Kehidupan pernikahan telah dijelaskan pada Perjanjian Lama, dan sekarang kita akan meninjau kehidupan pernikahan menurut Perjanjian Lama, tentu kita akan membahas berdasarkan 3 tahap :

Kitab Perjanjian Baru banyak juga menjelaskan baik dalam Kitab Injil maupun kita-kitab lain .maka penulis mengkajinya melalui 3 pandangan yaitu :

\section{Pandangan Yesus Kristus}

Pernikahan merupakan hal penting yang juga disoroti oleh Yesus dan menjadi bagian penting dalam kehidupan orang-orang Kristen masa itu, dan Tuhan Yesus diperhadapkan dengan orang-orang Farisi dan ahli-hali Taurat dan melalui pertanyaan-pertanyaan yang hanya mencobai Yesus dan disitulah Yesus menjelaskan kepada mereka arti pernikahan itu sendiri. 


\section{Pandangan Rasul Paulus}

Dalam surat 1 Korintus 7:1-16 Paulus menuliskan jawabannya atas persoalan jemaat yang ada disana yakni persoalan mengenai pernikahan. Mengenai pernikahan di dalam zaman itu, bahkan sampai di zaman sekarang ada dua pandangan ekstrim yang salah. Pertama, pernikahan adalah suatu keharusan (necessity) kalau seseorang tidak menikah, orang tersebut akan mendapatkan aib atau berarti Tuhan kurang memberkati orang tersebut. Pada umumnya pikiran ini dianut oleh kebudayaan Timur. Baik laki-laki maupun perempuan (perempuan lebih dituntut) akan dipaksa untuk menikah kalau sudah dewasa. Orang yang tidak menikah seperti ada sesuatu yang kurang atau tidak lengkap. Kedua, orang yang betul-betul mengasihi Tuhan dan mau hidup bagi Tuhan sepenuhnya harus meninggalkan pernikahan serta masuk dalam kehidupan membujang dengan demikian dianggap sebagai orang yang lebih kudus.

Bagi Paulus tidak menikah memang baik tetapi Paulus tidak berkata bahwa "hal itu lebih baik", yang dimaksudkan Paulus dalam hal ini adalah tidak menikah itu baik jika sesorang tersebut mampu melakukannya karena mereka menerima dari Allah karunia yang khas (ayat 7). Tuhan Yesus memberikan pengajaran tentang hal ini dalam Matius 19:10-12, yakni hal tersebut bergantung atas karunia Tuhan kepada tiap-tiap orang, bagi mereka yang mendapatkan karunia tidak menikah maka mampu untuk menahan diri dari keiginan hawa nafsu, jadi tidak menikah baik hanya alam keadaan khusus.

Sedangkan bagi orang-orang yang tidak mempunyai karunia membujang, Paulus menyatakan lebih baik menikah karena bahaya percabulan, supaya tidak hangus oleh hawa nafsu. Namun ini tentu bukan satu-satunya alas an mengapa harus menikah karena pada awal mula penciptaan sebelum manusia jatuh ke dalam dosa, pernikahan merupakan rancangan dari Allah yang ditetapkan-Nya di dalam Kejadian 2:18, Jadi pernikahan ada bukan karena dosa. Demikian Paulus juga memandang pernikahan bukan sebagai suatu keadaan yang kurang baik dan jangan seseorang menyangka bahwa mereka yang menikah berdosa. Paulus menyatakan "baiklah setiap laki-laki mempunyai istrinya sendiri dan setiap perempuan mempunyai suaminya sendiri". Pernyataan ini menyatakan tidak diizinkan seorang suami-istri memiliki lebih dari satu pasangan yang istilah sekarang dinamakan poligami.

Selanjutnya Paulus dengan tegas mengatakan bahwa yang ia katakan bukan ide dari diri sendiri tetapi perintah dari Tuhan, yakni seorang istri maupun suami tidak boleh menceraikan pasangannya. Namun bagi mereka yang telah bercerai ada dua pilihan, yaitu tetap hidup tanpa pasangan baru dalam artian tidak menikah lagi dengan orang lain atau kembali lagi pada pasangan yang lama. Konteks yang lainnya suatu pernikahan di mana ada pasangan yang belum percaya, dinyatakan kalau yang tidak percaya menceraikan, maka pernikahan itu tidak mengikat lagi. Namun Paulus menyatakan bagi pihak orang percaya untuk tidak menceraikan pasangan yang belum percaya, melainkan beriman bahwa suatu saat pasangan yang belum percaya itu bertobat dan menerima Yesus Kristus. Maka dalam hal ini perceraian tidak boleh terjadi karena inisiatif dari pihak orang yang sudah percaya.

Pernikahan dan rumah tangga adalah salah satu topik yang sangat menarik dan penting untuk dipelajari oleh orang Kristen, baik mereka yang sedang berencana untuk menikah maupun mereka yang telah menikah atau berumah tangga. Salah satu tujuan penting mempelajari topik ini agar "...kamu semua penuh hormat terhadap 
perkawinan..." (Ibrani 13:4a). Mengapa perlu menghormati pernikahan? Karena pernikahan dan rumah tangga adalah sebuah lembaga yang didirikan oleh Allah disamping pemerintah dan gereja. Dari ketiga lembaga ini yang paling tua adalah pernikahan atau rumah tangga. Jim E. Waldron mengatakan bahwa "Rumah tangga adalah institusi tertua... Rumah tangga adalah satuan masyarakat yang paling dasar. Seluruh peradaban bertahan atau hilang tergantung pada apakah kehidupan rumah tangga kuat atau lemah. Rumah tangga telah ada sejak permulaan waktu, dan tanpa diragukan akan selalu ada sepanjang manusia tetap hidup di muka bumi ini. Rumah tangga membentuk dasar setiap kelompok masyarakat"

Allah ingin supaya setiap pernikahan harus dilaksanakan sesuai dengan kehendakNya. Roy Deaver mengatakan bahwa "setiap pernikahan harus tunduk kepada hukum dan peraturan Allah" (Deaver dalam Warren, 1994: 6) ${ }^{26}$. Setiap rumah tangga tentunya menginginkan kebahagiaan. Hal itu hanya akan terwujud bila mengerti prinsip-prinsip pernikahan alkitabiah dengan benar. Bukan berarti tidak akan ada masalah sama sekali di dalam rumah tangga tetapi akan lebih dewasa menyelesaikannya sehingga rumah tangga tetap harmonis.

Berikut ini kita akan melihat beberapa prinsip alkitabiah pernikahan dan rumah tangga.

Perlu dipertimbangkan juga bahwa tidak mudah menjalankan tanggung-jawab sebagai ayah dan ibu untuk seorang anak, diperlukan kesiapan fisik, mental, emosi dan rohani, juga ekonomi. Pertimbangan ini dapat didasarkan pada pribadi suami dan isteri, apakah keduanya telah memiliki kesiapan-kesiapan ini atau sebaliknya. Suami dan isteri tidak cukup hanya siap secara ekonomi untuk memenuhi seluruh kebutuhan keluarga termasuk kebutuhan anak, tetapi keduanya harus benar-benar siap secara fisik, mental, emosi, rohani dan juga secara ekonomi. Dengan kata lain siap dalam semua bidang ini. Mungkin ada yang mengatakan ekonomi tidak begitu penting, tetapi Alkitab sendiri menegaskan pentingnya persiapan ekonomi (1 Timotius 5:8).

Seorang saudara seiman pernah menceritakan pengalaman yang diperolehnya bahwa pada tahun-tahun awal (satu atau dua tahun) pernikahan sebuah pasangan suami-isteri, biasanya baru menjalani masa penyesuaian diri satu sama lain, secara mental, secara emosional, saling mempelajari sifat masing-masing, berusaha untuk membuang ego (sifat mau menang sendiri), dan yang lebih penting lagi adalah merencanakan hal-hal (jangka panjang maupun jangka pendek) yang akan dilakukan untuk memenuhi kebutuhan-kebutuhan dalam rumah tangga. Setidaknya setelah melewati tahun-tahun awal inilah saat yang baik untuk memiliki anak. Hal ini juga akan memberikan sumbangsih besar untuk mengatasi hal-hal destruktif (menghancurkan) yang salah satu dampaknya dapat merugikan anak-anak dalam keluarga.

Pengalaman tidak semuanya salah. Kita dapat belajar dari pengalaman baik orang lain, yang dapat memberikan jalan bagi suami-isteri untuk menjalani kehidupan rumah tangga yang harmonis dan bahagia serta dapat menjadi teladan bagi keluarga lain.

${ }^{26}$ Waldron, Jim E, Is There A Universal Code Of Ethics?, I New Delhi-110064, 2001 


\section{Pandangan Para Teolog Terhadap Pernikahan Kristen \\ Pandangan Agustinus}

Status hidup menikah ditanggapi secara berbeda-beda oleh agama-agama. Sebagian besar umat manusia memandang pernikahan sebagai sesuatu yang wajar, alamiah dan sudah sepatutnya demikian. Ini merupakan pandangan yang umum. Akan tetapi, tidak sedikit kalangan tertentu yang memandang rendah pernikahan. Mereka melihat pernikahan sebagai sesuatu yang kotor, rendah dan jauh dari hidup kudus. Biasanya, yang disoroti adalah seks. Sikap negatif ini biasanya langsung ditindaklanjuti dengan menganjurkan kehidupan selibat atau membujang. Pandangan-pandangan yang serupa muncul pula di antara orang-orang Kristen tertentu.

Melalui tulisan ini kita hendak menggali konsep pernikahan melalui sudut pandang seorang bapa gereja besar bernama Agustinus. Pandangan Agustinus fair dan objektif adanya. Hal ini terbukti melalui tulisan-tulisannya seperti: Holy Virginity (Sancta Virginitate), On the Good of Widowhood (De Bono Viduitatis) dan On the Good of Marriage (De Bono Conjungali). ${ }^{27}$

Melalui tema-tema yang dia tulis ini kita bisa mengetahui bahwa Agustinus menghargai baik mereka yang membujang, menjanda \& tentunya juga yang menduda, maupun mereka yang menikah. Dia peduli baik kepada mereka yang menikah maupun yang tidak menikah. Bukunya On the Good of Marriage secara khusus membahas tentang topik nikah an sich. Salah satu tujuan penulisan buku ini ialah dalam rangka menjawab orang-orang yang terlalu mengagung-agungkan kesucian hidup berselibat sampai-sampai mendevalusi nilai-nilai pernikahan.

Melalui On the Good of Marriage Agustinus hendak mengangkat dan menempatkan kembali status menikah dalam terang kebenaran Firman Tuhan, tanpa dilebih-lebihkan dan tidak pula dikurang-kurangi. Di dalam buku itu Agustinus menguraikan tiga kebaikan dari status hidup menikah. Tiga kebaikan menikah itu berturut-turut terdiri dari beranak cucu (pleros), kesetiaan (fidei) dan sakramen (sacramentum). ${ }^{28}$ Selanjutnya marilah kita mengikuti penguraian Agustinus atas tiga kebaikan pernikahan ini satu demi satu;

\section{Beranak Cucu (Pleros)}

Manusia itu adalah makhluk sosial adanya. Beginilah beliau memulai bukunya dengan mengatakan: Manusia itu adalah makhluk social ini mendorong individuindividu untuk membentuk masyarakat. Kesatuan masyarakat yang paling asli, alamiah dan sederhana dimulai melalui pembentukan keluarga atau rumah tangga. Secara formal sebuah rumah tangga baru terbentuk pada saat dilangsungkannya pernikahan. Dengan disaksikan oleh keluarga dan sanak famili kedua belah pihak, sepasang pria-wanita itu berikrar membentuk sebuah keluarga. Status kedua orang itu yang sebelumnya adalah buyung \& upik dalam bahasa Minangkabau, atau ucok \& butet dalam bahasa Batak, sejak pernikahan telah berubah status menjadi sepasang suami istri. Tuhan sendirilah yang menggariskan pernikahan dengan menciptakan laki-laki dan perempuan. Di dalam penciptaan Tuhan sekaligus memberikan perintah kepada dua manusia mula-mula: "Beranakcuculah dan bertambah banyak; penuhilah

${ }^{27}$ David G. Hunter, "Marriage" Augustine through the Ages: An Encyclopedia, (Grand Rapids: Eerdmans, 1999), 535-536;

${ }^{28}$ David G. Hunter, "Marriage" Augustine through the Ages: An Encyclopedia 
bumi..." Perintah untuk beranak cucu berulang-ulang dikutip dan ditegaskan oleh Agustinus melalui berbagai ayat yang berbeda. Mulai dari pasal yang paling awal dari Alkitab, Kejadian 1, konsep pernikahan dan beranak cucu sudah ditegaskan. Bahkan, konsep itu sudah ada sebelum manusia jatuh ke dalam dosa di mana kejatuhan manusia baru terjadi di dalam Kejadian 3.

Jadi, beranak cucu bukanlah konsekuensi dari kejatuhan manusia ke dalam dosa. Setelah melahirkan anak, status pasangan suami-istri itu bertambah satu lagi, yakni menjadi ayah dan ibu. ${ }^{29}$ Status ini masih dapat diperpanjang terus. Setelah anak-anak besar lalu menikah sampai melahirkan anak pula, maka ayah dan ibu itu mendapatkan satu status baru lagi, yakni kakek dan nenek. Setiap status ini tidak dapat tidak selalu melibatkan pernikahan dan beranak cucu. Pernikahan merupakan amanat Ilahi yang universal dan terawal. Jadi, lembaga pernikahan itu sendiri baik adanya. Demikian pula dengan beranak cucu yang tercakup di dalam pernikahan. Bagi Agustinus, perlu dicatat di sini, bahwa walaupun sebuah pernikahan tidak disertai dengan melahirkan anak, hal itu sedikit pun tidak mengurangi kebaikan dari pernikahan. Pernikahan telah diinstitusikan oleh Allah sendiri pada masa yang paling awal, yakni dalam catatan penciptaan.

\section{Kesetiaan (Fidei)}

Tatkala melangsungkan upacara pernikahan, kedua belah pihak, sang pria dan si wanita, saling mengucapkan janji. Mereka bersumpah setia satu terhadap yang lainnya, baik sehat maupun sakit, baik suka maupun duka, baik kaya maupun miskin. Sumpah setia itu diikrarkan di hadapan Tuhan dan sesama manusia.

Seksualitas merupakan salah satu aspek yang tak terpisahkan di dalam pernikahan. Di sini, seorang suami dan seorang istri saling melayani satu sama lain. Dengan demikian mereka memenuhi tanggung jawabnya masing-masing. Dalam penjelasan yang panjang lebar tentang perkawinan, Rasul Paulus menegaskan: "Hendaklah suami memenuhi kewajibannya terhadap isterinya, demikian pula isteri terhadap suaminya" (1 Kor. 7:3). Bagi Agustinus saling memenuhi kewajiban merupakan "a mutual service" yang memang sudah sepantasnya demikian. Kesetiaan pun dituntut di dalam hubungan seksualitas. Bukan tidak mungkin di dalam sebuah pernikahan terjadi percabulan dan perzinahan. Agustinus tidak menutup-nutupi kenyataan ini. Akan tetapi, seandainya pun terjadi percabulan dan perzinahan di dalam suatu pernikahan, itu bukanlah berarti pernikahan menjadi tidak baik atau kekurangan nilai kebaikannya. Menurut Agustinus, yang benar adalah, percabulan dan perzinahan merupakan dosa dari orang-orang yang melakukan .Kedua dosa ini sering disinggung oleh Agustinus di dalam buku de Bono Conjungali.

Membahas kebaikan menikah, Agustinus banyak mengutip tulisan rasul Paulus di dalam perikop 1 Korintus 7. Dia menyinggung hampir setiap ayat di dalam perikop ini. Dalam seluruh kitab PL \& PB, perikop yang panjang lebar dan terlengkap mengupas perkawinan adalah tulisan Paulus tersebut. Bersamaan dengan berjalannya waktu, pasangan yang menikah tersebut saling melatih dan memupuk kesetiaan. Pernikahan menuntut sekaligus melatih pria dan wanita untuk saling berlaku setia satu sama lainnya. Mencermati zaman kita sekarang, adanya Pria Idaman Lain, Wanita Idaman Lain, perselingkuhan merupakan bukti konkret telah

${ }^{29}$ David G. Hunter, "Marriage" Augustine through the Ages: An Encyclopedia..., 400 
hilangnya apa yang Agustinus sebut sebagai kesetiaan. Kesetiaan patut dipertahankan dan dijaga oleh kedua belah pihak.

\section{Sakramen (Sacramentum)}

Yang dimaksudkan di sini jangan diasosiasikan dengan upacara sakramen yang diselenggarakan di dalam gereja-gereja Katolik dan Protestan. Adapun istilah sakramen yang dipakai oleh Agustinus di sini mengandung pengertian pertalian atau ikatan pernikahan. Sebagaimana yang sudah digariskan dalam Alkitab, seumur hidup mereka suami dan istri terikat menjadi satu, hanya maut yang akan memisahkan mereka berdua. Sewaktu menguraikan bagian ini Agustinus tidak melewatkan untuk menyinggung tentang perceraian. Baginya, Alkitab tidak pernah mengajarkan perceraian. Agustinus tidak lupa membahas pemberian surat cerai pada zaman Musa melalui perspektif yang Yesus sendiri ajarkan di dalam Mat. 9, Dia menegaskan kembali jawaban Yesus di dalam Mat.19:8; Beginlah Agustinus : menjelaskan Musa mengizinkan perceraian di kalangan orang Israel dengan memberikan surat cerai.

Hal ini sama sekali tidak boleh diartikan bahwa Musa setuju dengan konsep perceraian. Kenyataannya, Musa terpaksa berhubung dengan kekerasan hati atau ketegaran hati orang-orang Israel. Perlu kita ingat bahwa Agustinus menguasai bahasa latin dengan baik sekali. Besar kemungkinan sakramen yang dia maksudkan tidak lain dari apa yang dikatakan oleh Paulus di dalam Efesus 5:32, "Rahasia ini besar, tetapi yang aku maksudkan ialah hubungan Kristus dan jemaat." Dalam Alkitab berbahasa Latin "rahasia ini besar" diterjemahkan dengan memakai istilah magnum sacramentum.

Di dalam perikop ini rasul Paulus sedang menguraikan hubungan antara suami dan istri di dalam ikatan atau pertalian pernikahan. Uraian Paulus mengenai hubungan antara suami dengan istri kemudian beralih kepada hubungan antara Yesus Kristus dengan jemaat-Nya. Oleh karena itu, menurut Agustinus pernikahan mengajarkan kepada kita semua satu hal yang melampaui pernikahan itu sendiri, yakni relasi antara orang-orang percaya dengan Yesus Kristus. ${ }^{30}$

Orang-orang percaya merupakan mempelai wanita sementara Yesus Kristus adalah Sang mempelai pria. Pernikahan menjadi tanda atau simbol yang hidup yang bisa menolong kita untuk memahami hubungan antara Kristus dengan jemaat.

\section{Pandangan Marthe Luther Dan Calvin}

Baik Luther maupun Calvin menerima penegasan Yesus tentang perkawinan bahwa ikatan perkawinan pada dirinya tak terputuskan, namun berdasarkan Matius 5 : 32 ; 19 :9 mereka, seperti kekristenan timur menerima kekecualian: Zina istri ,tetapi juga alasan-alasan lain yang cukup berat .Berdasarkan kitab suci , yang memang tidak secara tegas melarag poligini dan dalam perjanjian Lama mengizinkan .

Luther dan Calvin mengatakan bahwa polgini memang dapat ditoleransi. Baik Luther maupun Calvin penganut Pesimisme Agustinus sehubungan dengan seksualitas genital, yang menjadi tempat: dosa asal" berpijak dan juga meracuni seksualitas yang dalam perkawinan diaktifkan ( Libidine et turpitudine infectum, Luther), yang karena itu tidak dapat menilai sebagai sakramen. ${ }^{31}$

\footnotetext{
${ }^{30}$ Hunter, "Marriage" Augustine through the Age, 536.

${ }^{31}$ C. Groenen OFM 'Perkawinan Sakramental,' (Yogyakarta: Penerbit Kanisius, 1993) 240-241
} 
Meskipun Luther dan Calvin menilai perkawinan sebagai suatu realitas “ duniawi " secular, yang berada dalam wewenang penguasa sipil,namun tidak berarti bahwa perkara "Profan " a religious, kendati pesimisme mereka terhadap seksualitas perkawinan sebagai sesuatu yang baik dan bahkan religious. Dalam Katekismus kecilnya Luther menegaskan ,Adapun keberadaan ( Status ) ilahi ( divinus) mereka yang menikah mesti dihiasi dengan kemeriahan besar, baik dengan berkat maupun dengan doa. ${ }^{32}$

Meskipun hidup itu itu gaya hidup sipil (Politicum genu vitae) Namun ia berdasarkan firman Allah, Kalau kita membaca Efesus pasal 5, saya enggan memulai dari ayat ke 22 karena itu akan membuat kita masuk ke dalam polemik-polemik Dunia tidak pernah mengerti bahwa pernikahan sesungguhnya adalah hubungan antara Kristus dengan jemaat dan itu berarti, pernikahan bukanlah sekedar adanya perasaan cinta di antara seorang laki-laki dengan perempuan. Pernikahan adalah satu representatif/ perwakilan dari hubungan Kristus dengan jemaat, sehingga di saat kita dengan isteri kita maju ke depan altar, itu berarti kita sedang mewakili Kristus dengan jemaat dan hubungan antara Kristus dengan jemaat itu harus di tonjolkan/ dinyatakan melalui kehidupan pernikahan. Oleh karena itu, orang seharusnya dapat melihat hubungan antara Kristus dengan jemaat melalui pernikahan. Ketika anak Tuhan menikah, maka pernikahan itu seharusnya dapat membawa kepada dunia satu representasi seperti ini dan ini merupakan satu gambaran yang begitu agung, yang merupakan rahasia besar (refiled apocaliptic)/ satu wahyu yang dibuka dari sesuatu yang tertudung/ pembukaan rahasia yang diberikan pada manusia.

Namun yang sungguh disayangkan adalah kalau orang Kristen ketika menikah tidak mengetahui konsep ini. Akibatnya, begitu banyak orang Kristen yang ketika masuk dalam pernikahan tidak mengerti mengapa pernikahan harus sedemikian uniknya dan kekristenan begitu serius mengurus pernikahan karena memang di dalamnya bukan sekedar pernikahan melainkan ada representasi antara Kristus dengan jemaat. Jikalau menikah menggambarkan representasi Kristus dan jemaat, maka apakah yang harus dimunculkan di dalam pernikahan Kristen.

Pertama: Pernikahan harus bersifat agung dan sacral karena pernikahan merupakan suatu relasi yang bersifat spiritual. Isteri taat mutlak kepada suami seperti jemaat taat mutlak kepada Kristus dan suami mengasihi isteri seperti Kristus mengasihi jemaat. Keagungan pernikahan harus dimulai dari sejak pertama kali kita menikah dan dijaga di dalam perjalanan pernikahan. Kita tidak boleh membiarkan pencemaran terjadi di dalam pernikahan kita. Akan tetapi, dunia tidak mengerti hal ini sehingga seringkalin the glorious married digantikan dengan the glamour married. Banyak pernikahan yang terlalu mewah tetapi tidak terdapat keagungan di dalamnya. Pernikahan tidak tergantung dari berapa mewahnya tetapi betapa agungnya. Agung dan mewah merupakan dua hal yang berbeda.

Saya pernah menghadiri pesta pernikahan yang dirayakan secara besar-besaran. Pada waktu itu, karena kemacetan lalu-lintas, mempelai tidak dapat datang tepat waktu. Namun demikian, karena padatnya acara-acara lain yang akan memakai gedung itu maka pengelola gedung itu mengeluarkan makanan di waktu yang telah ditetapkan, meskipun kedua mempelai belum datang. Pada waktu mereka tiba, maka para hadirin sudah asyik makan dan mengacuhkan mempelai yang berjalan masuk.

\footnotetext{
${ }^{32}$ Ibid., 241
} 
Sampai akhir acara, para hadiri sibuk sendiri dan tidak memperdulikan apa yang dilakukan oleh mempelai. Waktu itu saya sungguh-sungguh marah dan bertanya untuk apa sebenarnya mereka datang? Apakah mereka datang untuk menghormati mempelai ataukah hanya untuk makan? Seluruh acara itu sangat menghina mereka yang menikah seolah-olah mereka hanya hiasan di depan saja.

Oleh karena itu kami pada akhirnya memutuskan untuk tidak menyelenggarakan pesta pernikahan dan hanya kebaktian di gereja saja. Ketika kami menikah, hal ini menjadi suatu pergumulan yang besar. Kami ingin agar pernikahan kami tidak menjadi pernikahan yang mewah tetapi hina. Prinsip pertama adalah bahwa ibadah pernikahan haruslah sungguh-sungguh agung, dijaga dan dipelihara. Seluruh jalannya acara harus dijaga agar orang yang datang dapat melihat keagungan pernikahan itu.

Kita berada di dalam tantangan dunia yang besar. Bagaimana kita mau membangun pernikahan yang agung jikalau kita sudah memulainya tanpa keagungan? Jikalau kita sudah melecehkan pernikahan kita sendiri maka kita tidak mungkin dapat membangunnya dengan baik. Saya bukannya seorang yang anti pesta, tetapi yang saya tuntut adalah sakralitas dari pesta kita.

Kedua: Pernikahan juga mengandung aspek pertanggung-jawaban dari kita sebagai duta besar Allah di dalam dunia ini. Jikalau dunia ingin melihat mengenai bagaimana Allah kita, mereka seharusnya dapat melihatnya dari hubungan suamiisteri orang Kristen. Seorang anak yang mau melihat siapa Allahnya seharusnya dapat melihatnya dari hubungan orang tuanya. Melalui hubungan suami-isterilah dunia dapat melihat secara konkrit hubungan antara Kristus dan jemaat. Jikalau kita gagal merepresentasikan hubungan ini maka yang rusak bukan hanya kita melainkan nama Kristus dan jemaat.

Oleh karena itu pernikahan Kristen haruslah merupakan sesuatu yang diperjuangkan baik-baik, dengan takut dan gentar. Ini tidak terjadi secara otomatis. Banyak suami-isteri yang merasa pernikahan mereka lambat laun menjadi begitu membosankan dan serasa hanya berputar-putar, karena mereka sebenarnya tidak tahu apakah itu tujuan pernikahan. Jikalau mereka tahu betapa pentingnya arti pernikahan mereka, maka suami-isteri akan bersama-sama mencari bagaimana mereka dapat menjadi duta besar yang bertanggung-jawab.

Ketiga: Pernikahan seperti harus ditandai dengan sifat kekal. Hubungan Kristus dengan jemaat tidak dapat dihentikan dan tidak mengenal istilah kontrak, demikian pula hubungan suami-isteri berlangsung sampai kematian memisahkan. Di dalam hubungan seperti ini janganlah kita mengharapkan kesempurnaan tetapi lebih merupakan proses yang harus digarap terus-menerus sehingga menjadi sempurna.

Jikalau kita mengerti ketiga aspek ini maka kita mengerti apa artinya jikalau dikatakan bahwa pernikahan Kristen bukanlah sembarang pernikahan tetapi menjadi suatu representasi dari hubungan Kristus dan jemaat. Kita perlu membagi kebenaran ini kepada sesama orang Kristen karena terlalu sedikit orang Kristen yang mengerti hal ini. Di saat Saudara mulai membagikan kebenaran ini, maka Saudara akan menjadi berkat bagi orang lain. Saudara pun akan semakin mengingat kebenaran ini dan kehidupan pernikahan Saudara akan terus menerus dikoreksi.

Penelitian ini berhubungan dengan masalah : kebahagiaan dalam rumah tangga, kebahagiaan dalam rumah tangga menjadi barang yang sangat langka dalam zaman akhir ini, hal ini dikarenakan perkembangan zaman yang lebih mengutamakan 
keegoan daripada kebersamaan, jadi tidaklah mengherankan jika angka perceraian yang terjadi cukup tinggi saat ini. Kurangnya peran gereja juga menjadi salah satu pemicu tingginya angka perceraian, gereja hanya melakukan pekerjaan holistik gereja dan kurang ingin memberikan pemahaman tentang rumah tangga dalam kekristenan, khotbah tentang pernikahan hanya di dengar apabila ada pernikahan, paska pernikahan hal ini menjadi dilupakan, sesungguhnya perjalanan hidup berumah tangga sama pentingnya dengan hidup berjemaat. Seharusnya gereja mengambil peran untuk mereduksi efek samping dari kemajuan jaman yang ada.

Berdasarkan pengamatan peneliti dalam beberapa tahun ini, perceraian seringkali disebabkan oleh kurangnya suami menghargai istri dan mencintai mereka, kemudian istri merasa sebagai pemegang kendali dari perjalanan rumah tangga sehingga tidaklah mengherankan kita mendengar pada saat ini ada suami-suami takut istri. Budaya asal masing-masing pasangan satu dengan yang lain menjadi pemicu persoalan yang timbul.

Rasul Paulus dalam suratnya kepada Jemaat di Efesus, tentang dasar dari hubungan suami isteri adalah Kasih Kristus, untuk itu Peneliti membuat judul penelitian ini adalah : "Pengaruh Sikap Suami Istri Menurut Efesus 5: 22-33 Terhadap Kebahagiaan Keluarga".

\section{KESIMPULAN}

Berdasarkan acuan pada kajian teoritik dan berdasarkan hasil penelitian dan pembahasan sesuai fokus dan subfokus peneliti mengenai exegese Kitab Efesus 5:2233 sebagai pola pembinaan bagi pernikahan, maka ditemukan sebab-sebab lemahnya penerapan pola pembinaan bagi pernikahan di Gereja Bala Keselamatan Desa Pani'i dapat ditarik kesimpulan sebagai berikut:

Pertama, Pernikahan yang baik adalah komitmen total dari dua orang di hadapan Tuhan dan sesama. Pernikahan yang baik didasarkan pada kesadaran bahwa pernikahan ini adalah kemitraan yang mutual. Pernikahan yang baik juga melibatkan Tuhan secara proaktif di dalam setiap pengambilan keputusan, sebab pernikahan adalah sebuah rencana ilahi yang istimewa. Dengan demikian, pernikahan seharusnya tetap dijaga dan dipertahankan di dalam kekuatan Roh yang mempersatukan kedua insan.

Kedua menurut penulis pola pembinaan dalam pernikahan merupakan suatu metode yang paling efektif dalam memberikan pembekalan kehidupan suami istri melalui konseling pranikah dimulai dari :

1. Pengertian tentang hakekat pernikahan kristen

2. Mengetahui pernikahan itu adalah rencana dan rancangan Allah dalam hidup manusia.

3. Pentingnya pola diterapkan pada setiap pelayanan diharapkan dapat membuat pelayanan menjadi berkualitas. Setiap gereja memiliki pola yang menjadi ciri dalam pelayanannya, bukan hanya sekedar untuk membuat pelayanan kelihatan aktivitasnya namun untuk dapat memaksimalkan pelayanan yang dapat memenuhi kebutuhan jemaat.

Ketiga, pola pembinaan pernikahan Kristen yang telah menjadi bagian dari pelayanan gereja ini sejak lama tidak diterapkan dengan baik. Kegiatan-kegiatan ibadah yang mengedepankan pembinaan pemuda dalam menghadapi pergaulan dan 
perencanaan masa depan memlalui rencana penikahan yang ada pada dasarnya memiliki pola pengajaran yang sama. Hanya disebagian ibadah ketegorial yang memiliki sedikit perbedaan. Penyebabnya adalah hamba Tuhan tidak dapat melihat tanda-tanda perubahan zaman dan menyesuaikan pelaksanaannya dengan kondisi jemaat yang juga berubah. Hasilnya jemaat menjadi kurang peduli pentingnya pembinaan pernikahan

Keempat, pola pembinaan pernikahan tidak mendapat perhatian dari hamba Tuhan dan kurangnya pemahaman dari hamba Tuhan mengenai pola pembinaan disebabkan kurangnya pengalaman dalam pembinaan, dalam hal ini hamba Tuhan harus terus meningkatkan dan memperlengkapi diri melalui buku-buku serta perlunya berelasi dengan gereja lain atau hamba Tuhan baik dari denominasi yang sama maupun dari denominasi gereja yang berbeda.

Kelima, pembinaan melalui koseling merupakan pembelajaran khusus yang bertujuan untuk membentuk pasangan suami istri sampai akhirnya mereka memahmi benar arti sebuah pernikahan Kristen dan menjalani hidup sebagai pasangan suami istri.

Hamba Tuhan harus menerapkan pola yang dapat membuat pasangan suami istri merasa dewasa dalam menjalani kehidupan berumah tidak kehilangan esensi dari pembelajaran itu sendiri. Dalam penerapan pola ini, pemberitaa melalui firman Tuhan didaarkan pada kitab Efesus 5:22-33.

Pola itu, sesungguhnya di zaman ini sangat diperlukan dikarenakan pengaruhpengaruh sekuler yang begitu cepat mempengaruhi prilaku hidup dalam pernikahan yang dipengaruhi oleh :

1. Kekuatan Teknologi yang cepat sehingga antara kebutuhan dan keinginan tidak sesuai.

2. Komunikasi yang tidak harus dibangun ,justru membuat keretakan hidup suami istri dengan adanya perselingkuhan

3. Tayangan-tayangan yang tidak lagi terbatas dapat disaksikan sehingga membentuk pola kehidupan yang tidak lagi mengutamakan kesucian hidup.

Lemahnya pelayanan ini juga disebabkan: (a) Karena gereja kurang peduli akan pentingnya pembinaan sejak awal arti pernikahan Kristen (b) Gereja terlalu sibuk mengurusi hal-hal kegiatan gereja saja dan mulai meninggalkan perhatian kepada kehidupan keluarga. (c) Gereja tidak melaksanakan pola pembinaan sejak muda kepada pemuda-pemudi gereja untuk mempersiapkan hidup dalam berumah tangga (d) Karena kurang memperlengkapi diri, gereja tidak dapat menerapkan pola yang ada dalam Alkitab, sesungguhnya ada pola yang sangat ideal yang dapat diterapkan dalam pelayanan. 


\section{KEPUSTAKAAN}

Marulak Pasaribu,

2003 Pernikahan dan keluarga Kristen.Departemen Literatur YPPII ,Penerbit YPPII

Ramly. Lumintang, M.A. M.Th.

2010 Bahaya Posmodernisme \& peran kredo Reformed. Jawa Timur: Departemen Multimedia.

Jhon Piper /Justin Taylor .

2008 Seks dan supremasi Kristus. Momentum

J.L. Ch. Abineno .

2003 Sekitar etika dan soal-soal Etis. Jakarta: BPK Gunung Mulia

Scheunemann ,

2005 Romantika kehidupan suami-istri. Malang: Penerbit Gandumg Mas

Jhon Piper /Justin Taylor .

2008 Seks dan supremasi Kristus. Surabaya: Momentum

Dorothy I. Marx ,

2002 Itu Kan Boleh ? Bandung: Yayasan Kalam hidup

James \& Martha Reapsome .

2006 Rancangan Allah bagi pernikahan. Jakarta: Literatur Perkantas 